\title{
INTEREST GROUPS, ANTITRUST, AND STATE REGULATION: PARKER V. BROWN IN THE ECONOMIC THEORY OF LEGISLATION
}

\author{
WILliam H. PAGE*
}

The Parker doctrine requires that state regulatory arrangements seeking exemption from federal antitrust law bc clearly articulated by the state "as sovereign." Professor Page argues that the clear-articulation requirement is justified because it reinforces representative political processes. He rejects Professor Wiley's capture preemption approach and the Supreme Court's analysis in Fisher v. City of Berkeley, arguing that both misconceive the nature of governmental relationships with interest groups. Professor Page concludes that the essentially collective nature of economic regulation supports adherence to the clear-articulation requirement as the measure of political legitimacy.

Under the doctrine of Parker v. Brown, ${ }^{1}$ an anticompetitive arrangement may be exempt from the antitrust laws if it is part of a state regulatory regime. Neither conventional price theory nor welfare economics can justify this doctrine: cartels like the raisin prorate program at issue in Parker are inefficient and, if anything, more durable and costly because they are enforced by the state. ${ }^{2}$ Indeed, despite the vast body of case law and academic commentary that Parker has provoked, ${ }^{3}$ there is little agreement concerning a justification for the doctrine and still less concerning the particular form the doctrine should take.

- Visiting Professor of Law, Boston University School of Law; Professor of Law, Mississippi College School of Law. B.A., Tulane University, 1973; J.D., University of New Mexico, 1975; LL.M., The University of Chicago, 1979. I gratefully acknowledge critiques of earlier drafts by Craig Callen, Ronald Cass, Arthur Cornell, John Lopatka, Henry Manne, and Cass Sunstein. I also have benefited from the comments of participants in the National Endowment for the Humanities seminar on "The Founders' Constitution" at the University of Chicago and in a faculty workshop at Mississippi College School of Law.

1. 317 U.S. 341 (1943).

2. They may, however, be less inefficient in the short run because of regulators' political incentives to consider consumer interests. See Peltzman, Toward a More General Theory of Regulation. 19 J.L. \& ECoN. 211, 217 (1976).

3. For an excellent survey of both, see Lopatka, The State of "State Action" Antitrust Immunity: A Progress Report, 46 LA. L. REv. 941 (1986). More recent contributions to the body of academic commentary include Garland, Antitrust and State Action: Economic Efficiency and the Political Process, 96 YALE L.J. 486 (1987); Gifford, The Antitrust State Action Doctrine After Fisher v. Berkeley, 39 VAND. L. REv. 1257 (1986); Jorde, Antitrust and the New State Action Doctrine: A Return to Deferential Economic Federalism, 75 CALIF. L. REv. 1401 (1987). 
Six years ago, I suggested a rationale for the central feature of the current doctrine, which is the requirement that anticompetitive state legislation be "clearly articulated and afirmatively expressed as state policy," if it is to be exempt from the federal antitrust laws. ${ }^{5}$ I argued that the rule reinforces representative pohtical processes by ensuring that the decision to displace antitrust is made ouly after competing interest groups have survived the traditional Madisoman gauntlet of legislative procedures. Two events have made a reconsideration of this analysis appropriate. First, in a recent issue of the Harvard Law Review, Professor John Shepard Wiley attacked my rationale for the clear-stateinent approach and proposed a radical new "capture preemption" approach purportedly drawn from the economic theory of legislation. ${ }^{6}$ Simultaneously, the Supreme Court decided Fisher v. City of Berkeley, ${ }^{7}$ which upheld a municipal rent control ordinance against an antitrust attack, not on the ground that it was exeinpt under Parker, but on the ground that it did not involve the necessary "contract, combination .... or conspiracy." 8 Both the article and the decision call the logic of the modern Parker doctrine into question.

I will argue here that both Professor Wiley and the majority in Fisher are wrong for essentially the same reason: they misconceive the nature of governmental relationships with interest groups and, in particular, the role of institutional arrangennents within government in defining those relationships. Once the conceptual basis for the Parker doctrine is understood, the shortcomings of the approaches of Professor Wiley and the Fisher majority becoine apparent. The issue, like much recent legal scholarship, ${ }^{9}$ concerns the proper judicial response to the problem of rent

4. California Retail Liquor Dealers Ass'n v. Midcal Aluminum, Inc., 445 U.S. 97, 105 (1980) (quoting City of Lafayette v. Louisiana Power \& Light Co., 435 U.S. 389, 410 (1978)). The test also requires "active state supervision" except where the allegedly unlawful conduct is by a public entity. Town of Hallie v. City of Eau Claire, 471 U.S. 34, 46-47 (1985).

5. Page, Antitrust, Federalism, and the Regulatory Process: A Reconstruction and Critique of the State Action Exemption After Midcal Aluminum, 61 B.U.L. Rev. 1099, 1115-25 (1981).

6. Wiley, A Capture Theory of Antitrust Federalism, 99 HARv. L. Rev. 713 (1986). Professor Gifford also criticizes my approach, but for different reasons. See Gifford, supra note 3, at 1304. First, he says that I exaggerate the political accountability of state legislatures, especially when the burdens of state regulation fall on nonresidents. Second, he says that I do not adequately explain the application of the clear-articulation requirement to municipalities. Finally, he says that the cleararticulation requirement is a nullity; courts cannot or will not enforce it. I address Professor Gifford's first point in Page, supra note 5, at 1103-04. The remaiming points I address infra in text accoinpanying notes $113-21$ and $132-48$.

7. 475 U.S. 260 (1986).

8. Id. at 206 (quoting 15 U.S.C. $\S 1$ (1982)). Not coincidentally, Professor Wiley has also analyzed the Berkeley case, and found in it similarities to his approach. See Wiley, The Berkeley Rent Control Case: Treating Victims as Villains, 1986 SuP. CT. REv. 157, 166-72.

9. See, e.g., Ackernian, Beyond Carolene Products, 98 HARv. L. Rev. 713 (1985); Aranson, Gellhorn \& Robinson, $A$ Theory of Legislative Delegation, 68 CoRNELL L. REv. 1 (1982) [hereinaf- 
seeking ${ }^{10}$ by interest groups in the political process.

In Section I of this article, ${ }^{11} \mathrm{I}$ introduce the Parker doctrine and provide an overview of the current dispute over the doctrine's effectiveness. In Section II, ${ }^{12}$ I first outline the critique of the clear-statement approach. Then I argue that the focus of tlie clear-statement approach on legislative-as opposed to administrative or municipal-policy choices, and on clear as opposed to vague legislative choices, is fully justified by political and economic theory. In Section III, 13 I show that Professor Wiley's suggestion of capture as a basis for preemption is both unworkable and insupportable in principle. Lastly, in Section IV, ${ }^{14} \mathrm{I}$ apply the insights of the analysis to the Court's definition of governmental "agreement" in the Fisher case.

\section{BACKGROUND}

\section{A. Present Law and Its Rationale.}

To a large degree, state regulation is simply the extension of private monopolistic activity into the governmental spliere. ${ }^{15}$ Were that the extent of the problem, the Parker doctrine would be an intolerable anomaly in a federal antitrust policy purportedly defined by economic efficiency. ${ }^{16}$ To find a justification for the doctrine, however, one inust look to the principle-developed in constitutional law in the decade before Parker ${ }^{17}$ —of judicial deference to state economic clioices whose costs

ter Legislative Delegation]; Bruff, Legislative Formality, Administrative Rationality, 63 TEX.L. REV. 207 (1984); Easterbrook, The Supreme Court, 1983 Term-Foreword: The Court and the Economic System, 98 HARV. L. REv. 4 (1984); Farber \& Frickey, The Jurisprudence of Public Choice, 65 TEX. L. REv. 873 (1987); Macey, Promoting Public-Regarding Legislation Through Statutory Interpretation: An Interest Group Model, 86 ColuM. L. REV. 223 (1986); Posner, Economics, Politics, and the Reading of Statutes and the Constitution, 49 U. CH1. L. REV. 263 (1982); Sunstein, Interest Groups in American Public Law, 38 Stan. L. RI:v, 29 (1985).

10. See generally Buchanan, Rent Seeking and Profit Seeking, in Toward A TheORY OF THE RENT-SEEkING SocietY 3 (J. Buchanan, R. Tollison \& G. Tullock eds. 1980) ("So long as owners of resources prefer more to less, they are likely to be engaged in rent seeking, which is simply another word for profit seeking.").

11. See infra notes $15-49$ and accompanying text.

12. See infra notes $50-148$ and accompanying text.

13. See infra notes 149-216 and accompanying text.

14. See infra notes 217-55 and accompanying text.

15. See G. Stigler, The Citizev and The State 114-41 (1975).

16. See, e.g., Page, Antitrust Damages and Economic Efficiency: An Approach to Antitrust Injury, 47 U. CHI. L. REV. 467, $471-72$ (1980); Page, The Scope of Liability for Antitrust Violations, 37 STAN. L. REv, 1445, 1451 n.32 (1985) (summarizing literature). For public antitrust enforcement, see, e.g., Campbell, The Antitrust Record of the First Reagan Administration, 64 TEX. L. REV. 353 (1985) (evaluating Administration's performance in promoting economic efficiency).

17. See generally McCloskey, Economic Due Process and the Supreme Court: An Exhumation and Reburial, 1962 SuP. CT. REv. 34, 35 (tracing "the decline and virtual demise of "economic due process" " in the years 1937-1962). 
and benefits fall primarily on the citizens of the state. ${ }^{18} \mathrm{It}$ is nothing new to apply this principle to the analysis of state legislation under the supremacy clause. The Court has long recognized that a due regard for state sovereignty and a proper awareness of the himits of judicial competence require that congressional intent to preempt be particularly explicit in areas traditionally regulated by the states. ${ }^{19}$

Since 1975, however, the Supreme Court has modified Parker's deferential approach. In its current formulation, the state action doctrine requires that the challenged regnlatory scheme be clearly articulated by the state as sovereign, ${ }^{20}$ that is, through legislative processes. ${ }^{21}$ Policies that originate in subordinate bodies such as regnlatory agencies and municipalities are not entitled to exemption. ${ }^{22}$ In my 1981 article, I argued that this more recent element of the Court's approach is a product of the Court's increased awareness of the political shortcomings of the regulatory process. ${ }^{23}$ The restriction to acts clearly articulated by the state as sovereign is a necessary and effective qualification of Parker's deference; it ensures that state regulatory policies in conflict with antitrust will be inade in representative bodies after a full Madisomian reconcitiation of conflicting interests, ratler than in administrative bureaucracies. This approaclı implicitly recoginzes that administrative or municipal regula-

18. See Page, supra note 5, at 1102-03. The connection between the economic due process cases and Parker was first identified in Verkuil, State Action, Due Process, and Antitrust: Reflections on Parker v. Brown, 75 Colum. L. Rev. 328 (1975).

19. See generally L. TRIBE, AMERICAN CONSTITUTIONAL LAW 385 (1978) (discussing Rice v. Santa Fe Elevator Corp., 331 U.S. 218, 230 (1947)). See also Parker, 317 U.S. at 351 ("In a dual system of government in which, under the Constitution, the states are sovereign, save only as Congress may constitutionally subtract from their authority, an unexpressed purpose to nullify a state's control over its officers and agents is not lightly to be attributed to Congress.").

20. California Retail Liquor Dealers Ass'n v. Midcal Aluminum, Inc., 445 U.S. 97, 105 (1980). The test also requires "active-supervision" by the state, $i d$., except where the allegedly unlawful conduct is by a public entity. Town of Hallie v. City of Eau Claire, 471 U.S. 34, 46-47 (1985). In my earlier article, I criticized the active supervision requirement as inconsistent with the process basis for the Parker Doctrine. See Page, supra note 5, at 1125-36. For criticism of the requirement from a different perspective, see Lopatka, supra note 3, at 1002-05 (arguing that "marginal benefit of a supervision requirement" in decreasing cost of error in interpretations of intent may be outweighed by cost of compliance).

21. These may include actions by the state's supreme court within its legislative authority. See Hoover v. Ronwin, 466 U.S. 558, 568 (1984).

22. See, e.g., Community Communications Co. v. City of Boulder, 455 U.S. 40, 52 (1982) (A municipality's ordinance is not exempt "unless it constitutes the action of the [state] itself in its sovereign capacity or muncipal action in furtherance or implementation of clearly articulated and affirmatively expressed state policy." (citations omitted)); Cantor v. Detroit Edison Co., 428 U.S. 579, 595-97 (1976) (agency action not exempt unless necessary to effectuate the regulatory act). See generally J. Vining, The Authoritative and the Authoritarian (1986) (arguing that bureaucratic choices are not authoritative).

23. Page, supra note 5, at 1101 . For an excellent more recent treatment of the evolution of ideas of regulation, see T. MCCRAw, Prophets of Regulation (1984). 
tion under vague statutory standards may fail as a political process, and therefore does not warrant deference under the traditional rationale.

Thus, the shape of the Parker doctrine, like the shape of much constitutional doctrine, ${ }^{24}$ is determined by the Court's concern with the process of representation. Government is a mechanism for collective choice, but differing institutional arrangements within government seriously affect the kinds of interests represented and hence reflected im governmental action. Under the "second-look" approach, administrative decisions in apparent conflict witly constitutional or legislative norms that are superior to the agencies' enabling legislation are invalidated, throwing the question back to the legislature. ${ }^{25}$ While this techirique almost certainly reduces the incidence of anticompetitive regulation, it does so by prescribing legitimate lawmaking purposes rather than legitimate outcomes. The approach permits states to adopt efficient regulation to deal witl both market failure and antitrust failure.

At the same time, the approach is in accord witlı the proper judicial role in a democracy. The Court need not determine directly the economic legitimacy of state economic regulation, a task it has emphatically declined under the fourteenth amendment. ${ }^{26}$ Indeed, it is in the nature of deference to permit inefficient regulation that has been democratically enacted. Under this approach, the Court also does not need to determine directly the political adequacy of state lawmaking processes. Duly enacted, explicit legislation in conflict witl federal antitrust law is viewed as legitimate or authoritative, while regulation without sucli explicit legislative authorization is presumed illegitimate. Appropriately, this approach may be analogized to an "antitrust" as opposed to a "regulatory" technique: "rather than dictate substantive results it intervenes only when the 'market' . . . is systematically malfunctioning."27

\section{B. The Doctrine's Discontents.}

1. The Capture Critique. Critics of the Parker doctrime have repeatedly empliasized the inconsistency of mucli state regulation with the terms or policy of the antitrust laws. Recently, for example, one commentator argued that the antitrust laws should preempt any state or municipal regulation that is not justified by a plausible market failure

24. See generally J. ELY, Democracy and DisTRust (1980) (illustrating a theory of judicial review consistent with democratic theory).

25. See Farber \& Frickey, supra note 9, at 914-16 \& nn.245-46 (discussing Hampton v. Mow Sun Wong, 426 U.S. 88 (1976), and other cases involving remand to legislature).

26. See McCloskey, supra note 17 , at 38 .

27. J. ELY, supra note 24, at 102-03. 
rationale. ${ }^{28}$ Such an approach superficially reconciles antitrust with regnlation; it permits state displacement of antitrust only where there is reason to believe antitrust enforcement will not produce efficient outcomes. It ignores, however, the concern with institutional competence that is at the heart of the Parker doctrine: legislatures displace competition for a host of reasons, and it is beyond judicial competence to isolate good from bad anticompetitive schemes.

Professor Wiley attempted to answer these political concerns in his recent critique. Drawing on the economic theory of legislation, he suggests that certam state economic choices, no matter how clearly articulated, are not only imefficient but illegitimate because they are the result of a regulated group capturing the state's pohtical system. Parker itself, he says, was not based merely on deference to state econormic choices, but on an unquestioning acceptance of the economic benefits of regulation..$^{29}$ The Court, im his view, was not merely willing to accept the considered choice of the legislature; it enthusiastically accepted the public interest rationale for the raisin prorate program. Under this view, the erosion of Parker's deferential approach in the post-1975 cases is based on a growmg distrust of the asserted public interest rationale for regulation ${ }^{30}$ and not of the political adequacy of the regulatory process.

The notion of regulatory capture is nothing new. Indeed, the public interest conception of regulation has wrestled with the notion of regulatory capture since the 1920 s. $^{31}$ Modern empirical studies, however, have demonstrated that regulation often benefits the regulated producers themselves rather than the public. ${ }^{32}$ The emerging economic theory of legislation ${ }^{33}$ reveals the reason for this disparity. The free-rider problem hinders large, diffuse groups in protecting their interests. For example, although the effect of a given regulatory issue on consumers as a group may be great, the stake of each consumer is normally too small to justify his or her individual imvestment in political activity. Additionally, organizing consumers to aggregate their investments is difficult, because any benefit from the investments will be spread over all consumersregardless of whether they actually imvest. ${ }^{34}$ In other words, consumers

28. Cirace, An Economic Analysis of the "State-Municipal Action" Antitrust Cases, 61 TEX. L. REV. 481 (1982).

29. Wiley, supra note 6 , at 715-19.

30. Id. at $719-28$.

31. For an account of the development of the capture notion, see McCraw, Regulation in America: A Review Article, 49 Bus. Hist. Rev. 159, 162-64 (1975).

32. Wiley, supra note 6 , at $723-24$.

33. For a useful summary of the literature, see Macey, supra note 9, at 227-33.

34. See id. at 230-31; cf. M. Olson, The LOGic of Collective Action 127-28 (2d ed. 1971) (noting that small "special interest" groups wield disproportionate power). 
have an incentive to free ride on the efforts of others. The regulated group, however, is compact and highly interested, and therefore better able to internalize the benefits of investment in the political process.

Professor Wiley argues that the Court, despite its dim recognition of the pernicious influence of interest groups im the political process, has failed to develop a doctrine equal to the problem. In his view, the clearstateinent approach is a "miserable procedural compromise." $35 \mathrm{He}$ concludes that where capture is found, normally by inference from the face of the statute, the state law should be preempted. In effect, his approach is a heightened form of rationahty review, or what one commentator has called a "prohibition of naked preferences,"36 although in a context im which the Court has not enforced that prohibition. Wiley's theory goes beyond the simple economic critique of Parker, however, by advancing "capture" as a criterion of pohtical legitimacy.

2. The Dimensions of the Dispute. Parker was decided largely on the ground that the Court was unwilling to reenter the pohtical mire of the Lochner era under the guise of Sherman Act preemption analysis. ${ }^{37}$ Now, with the reemergence of substantive due process review in other guises, ${ }^{38}$ with the growth of an economic literature that systematizes the laissez-faire intuitions of the Lochner-era Court, ${ }^{39}$ and with the appearance of a legal literature arguing that special interest legislation should be held unconstitutional, ${ }^{40}$ Professor Wiley is prepared to argue that the Parker doctrine should be overruled and just such an inquiry undertaken. ${ }^{41}$

Although Professor Wiley and I offer radically different approaches, there are numerous points of agreement in our assumptions. Both of us

35. Wiley, supra note 6, at 715 .

36. Sunstein, Naked Preferences and the Constitution, 84 CoLum. L. Rev. 1689, 1689 (1984).

37. Verkuil, supra note 18, at 331-33.

38. See, e.g., Jackson \& Jeffries, Commercial Speech: Economic Due Process and the First Amendment, 65 VA. L. REv. 1 (1979).

39. See, e.g., R. POSNeR, ECONOMIC ANALYSIS OF LAW $589-93$ (3d ed. 1986).

40. See, e.g., R. Epstein, Takings: Private Property and the Power of Eminent DoMAIN 306-29 (1985) (arguing that public transfers and welfare programs are unconstitutional); B. SIEGAN, ECONOMIC LIBERTIES AND THE CONSTITUTION (1980) (advocating closer judicial scrutiny of social and regulatory legislation); Mashaw, Constitutional Deregulation: Notes Toward a Public, Public Law, 54 TUL. L. REv. 849, 851 (1980) (proposing "a new cause of action, a claim to publicregarding legislation ... a cause of action grounded in no particular text, but in the Constitution as a whole"); Sunstein, supra note 36, at 1698, 1727-30 (examining whether Court's commitment to prohibiting distribution of resources based on wielding of raw political power, as exemplified by rationality review, is "merely rhetorical").

41. Professor Wiley's approach would uphold the result in Parker because the raisin prorate program was consistent with federal regulation, see Wiley, supra note 6 , at $716 \mathrm{n} .10,745$, but would overrule the Parker doctrine, id. at 739-41. 
accept economic efficiency as the primary goal of antitrust law. ${ }^{42} \mathrm{We}$ also agree that state economic regulation is frequently in sharp conflict with that goal, largely because of the problem of rent seeking by interest groups. ${ }^{43}$ We agree, moreover, that the federal courts should not intervene in state economic choices absent some defect in the political system that the courts can correct. 44 This last point of agreement is critical: like most writers on antitrust federalism, 45 both Professor Wiley and I explicitly turn to constitutional doctrine and theory for guidance in deterimining the validity of state regulation under the antitrust laws. ${ }^{46}$

These points of agreement set the framework for our dispute. My clear-statement approach is structural, ${ }^{47}$ seeking to take account of perceived failures in the state political process, while preserving ultimate state legislative control. Professor Wiley's approach is substantive, ${ }^{48}$ preempting certain state economic choices no matter how explicitly chosen through legislation or otherwise. The basis of this difference hes in our conflicting views of the nature and significance of capture. The clearstatement approach treats capture as a kind of colloquial characterization of one outcome in a political process that inevitably involves contending interest groups. Where a simgle interest has won favorable regulation, as indicated by the regulation's conflict with antitrust, one inay say that the interest has captured the legislative process. The inference is not, however, that the regulation is itself illegitimate, only that the process by whicli it was enacted may not have taken account of the full range of interests affected. Some interests will inevitably be more effective in the political process because of the free-rider problem; but differing institutional arrangements can affect the extent of the advantage enjoyed. Thus, judicial intervention is justified when regulation that conflicts with antitrust exploits an independent defect in the process of representation. The function of intervention, then, is to resubmit the issue to the state pohitical process for fuller consideration.

Professor Wiley, in contrast, views capture-or the free-rider problem that perimits it-as itself a defect in the pohtical process and, in fact,

42. Professor Wiley is somewhat grudging on this point, however. See id. at 735-48.

43. See id. at 765. For a discussion of the rent-seeking problem, see M. OLSON, supra note 34, at $127-28$.

44. See Wiley, supra note 6 , at $766-69$.

45. See, e.g., Easterbrook, Antitrust and the Economics of Federalism, 26 J.L. \& Econ. 23 (1983); Verkuil, supra note 18, at 329.

46. See Wiley, supra note 6, at 756-64; infra notes 16-27 and accompanying text.

47. For discussion of various structural approaches, see Farber \& Frickey, supra note 9, at 91420.

48. In theory, capture may be defined either procedurally, focusing on the lobbying process, or substantively, focusing on the legislative outcome. Only the substantive definition, however, is practicable as a legal standard. See infra notes 60-148 and accompanying text. 
the only relevant defect. ${ }^{49}$ It is different in principle from other regulatory outcomes and can be judicially distinguished as such. Capture alone thus justifies federal intervention regardless of what branch of state government is captured or the circuinstances in which capture occurs. Thus, any concern with other purported defects in the political process is useless or counterproductive. Consistently, Wiley recommends intervention in the forin of preeinption, entirely foreclosing the state from that form of regulation, in the absence of express congressional permission.

A consideration of these points of disagreement requires an exploration of interest-group dynamics in legislative and bureaucratic processes. Once the relationship between interest-group pressure and political decisionmaking is more fully understood, the choice between doctrinal alternatives will be clear.

\section{INTEREST GROUPS AND INSTITUTIONAL STRUCTURE}

\section{A. The Critique of the Clear-Statement Approach.}

Professor Wiley attacks the clear-statement approach on the ground that it is ineffective and costly..$^{50} \mathrm{He}$ charges that my rationale "fails to justify adequately the state action doctrine's attack on delegation, [and that my] reasoning rests on the premise that capture problems infect agency policymaking more than they infect legislative decisionmaking." 51 Professor Wiley states that this premise is incorrect because producer groups have the same cost advantages in the legislative process as they have in the adinimistrative process. ${ }^{52}$ Indeed, he argues, legislatures inay be more susceptible to capture because they are less insulated from electoral pressures. ${ }^{53}$

Professor Wiley further argues that, because capture of the legislature is at least as easy as capture of an agency, the clear-statement approach is at best a nulhty: it simply asks interest groups to direct the legislature to make protection statutorily exphicit. This, he argues, may be worse than nothing because it forces states to make state sanctioned cartels inore rigid. ${ }^{54}$ Moreover, to the extent that the approach discourages delegation of regulatory authority, it inhibits efficient governmental organization. ${ }^{55}$ In the saine vein, it "[i]nsults state sovereignty by telling

\footnotetext{
49. Wiley, supra note 6 , at $765-69$.

50. Id. at 733-36.

51. Id. at 732 .

52. $I d$.

53. Id.

54. Id. at 733.

55. Id. at 733-34.
} 
states how they will be allowed to effectuate their state policies."56

Professor Wiley also contends that, with respect to municipalities, the clear-statement approach is even more damaging, because it undermines local autonomy-a policy consistent with what le calls the populist goals of antitrust. ${ }^{57}$ According to Professor Wiley, the approach also actively discourages efficient regulation of natural monopolies. ${ }^{58}$ Lastly, Professor Wiley argues that federal courts are not imclined to struggle with the state law questions required by the clear-statement approacli. ${ }^{59}$

\section{B. The Legislative Versus Administrative Structure.}

1. Some Basic Distinctions. Professor Wiley's attack, while admirably colierent, is based on a theory of administrative and legislative processes that is extraordinarily simplistic and unresponsive to the legitimate concerns of federalism. In this respect his arguments do not differ from most capture theories that are "largely institution-free." 60 One recent study, for example, models the political process as a matter of competition among interest groups, ignoring voters and representatives "because they are assumed mainly to transmit the pressure of active groups." 61 The economic theory of politics, lowever, is still developing. Understandably, earlier theories did not distinguish institutional factors for reasons of clarity. ${ }^{62}$ Likewise, because it is not their function, empirical studies showing who benefits from various forms of regulation do not normally identify the point at which capture occurs in the political process. It is nonetheless clear that imstitutional factors play an important role in determining political beliavior. ${ }^{63}$ As one critic has said, "different types of constitutionally empowered agents on the political scene-bureaucrats, judges, legislators, and elected executives-each bring distinct motivations, authorities, and constraints into the process of political excliange that leads to the final regulatory outcome." 64

Equally important, Professor Wiley's attack misconceives the clearstatement approach as requiring legislative capture as opposed to adinin-

56. Id. at 736 (emphasis in original).

57. Id. at 735 .

58. Id. at 733-35.

59. Id. at 736 .

60. Kalt \& Zupan, Capture and Ideology in the Economic Theory of Politics, AM. Econ. REv., June 1984, at 279, 298.

61. Becker, $A$ Theory of Competition Among Pressure Groups for Political Influence, 98 Q.J. ECoN. 371, 372 (1983).

62. See, e.g., Peltzman, supra note 2, at 211 (treatimg behavior of administrators and legislators as subject to same determinants).

63. Kalt \& Zupan, supra note 60 , at 298.

64. Hirshleifer, Comment, 19 J.L. \& EcoN. 241, 242 (1976) (criticizing Peltzman, supra note 2). 
istrative capture. In reality, a proper clear-statement approach does not hinge on the existence of capture at any level of government, but on an explicit legislative choice to displace antitrust rules. When vague legislation is interpreted by an agency in a way that conflicts with antitrust rules, that interpretation may simply follow a hidden legislative intent to benefit a particular interest group, or it may decide issues left unresolved by the legislature. In the first instance, if there is capture, it is capture of the legislature; in the second, it is of the agency-but the clear-articulation requirement would invalidate both.

An explicit legislative choice in conflict with the antitrust laws is entitled to greater deference on botl political and economic grounds than the choice in either of these cases. Where legislation simply delegates the essential policy choice to an agency, the issue is whether legislative or administrative clioices are entitled to greater deference. Where hidden legislative preferences are enforced by regulation, the issue is whether clear rather than hidden legislative preferences are entitled to greater deference. Note, lowever, that while I divide these cases for analysis, the clear-statement approach does not require that a court make any such distinction. ${ }^{65}$

Note also that my argument does not advocate the application of an invigorated nondelegation doctrine to the states. Broad legislative delegations at the federal level may or may not be antidemocratic or inefficient. ${ }^{66}$ In the vast range of legislative action, however, it is of no federal concern that the state chooses to delegate policymaking authority to administrators. The requirement of a clear legislative choice comes into play only when the state's policy choice conflicts witl federal antitrust law. In this circumstance it is not the inere vagueness of the legislative action, but the conflict of the regulatory outcome with a higlier nornfederal antitrust rules-that justifies federal action to assure popular consent. Thus, Professor Wiley's claim that the approach inhibits legislative delegations and thereby intrudes on states' prerogatives in defining their governmental structures is at best overstated-and certainly ironic in view of the far more sweeping intrusion his own capture preemption approach would entail.

Professor Wiley's criticisin of the clear-statement approach's preference for legislative choices goes only to the economic issue of whether that approach reduces the incidence of anticompetitive regulation. While

65. Thus it is unnecessary to resolve whether the "pure policy lottery"-my first case- - is ... a mere conceptual category." Mashaw, Prodelegation: Why Administrators Should Make Political Deeisions, 1 J.L. Econ. \& ORG. 81, 90 (1985).

66. Compare id. with Legislative Delegation, supra note 9, at 55-63 (discussing possible explanations for delegation of legislative authority to regulatory agencies). 
I argue that it does, his focus obscures the political differences between legislative processes on the one hand and administrative and nunicipal processes on the other, differences that also affect the degree of deference due to those processes.

It is a cornerstone of constitutional law that legislatively adopted policies are generally entitled to greater deference than those adopted by the executive or independent agencies. When the rule in question is in apparent conflict with a higher norm, a court will view the rule far more restrictively when it is adopted by an executive body or independent agency without explicit legislative authorization. ${ }^{67}$ In Professor Wiley's view, this distinction is ineaningless and even perverse, since there are no differences between legislative and bureaucratic processes that are relevant to the issue of deference. States, he argues, should be able to organize their governmental policymaking structure in any way they choose. His reasoning, however, trivializes the unique features of the legislative process that are central to constitutional government.

2. Interest Groups in the Legislative Process. Since the founding of our government, the fundamental criterion for the exercise of governmental power has been popular consent. ${ }^{68}$ Consent is secured by constitutional, republican government with certain critical attributes, particularly representation in elective bodies that are controlled by a complex system of institutional checks. It is an essential feature of this scheme tliat competing groups participate in the process of lawinaking. The Noerr-Pennington doctrine exphicitly recognizes the legitiniacy of interest-group activity, even in frank lobbying for protectionist state legislation. ${ }^{69}$

This conception of the role of interest groups in government is fully consistent with the understanding of the framers. Madison's faniliar negative definition of the problem of factions ${ }^{70}$ should not obscure the

67. See, e.g., Fullilove v. Klutznick, 448 U.S. 448, 472-73, 480-81 (1980).

68. See THE Federalist No. 22, at 110 (A. Hamilton) (M. Beloff ed. 1987); THE FEderalisT No. 49, at 257 (A. Hamilton (or J. Madison)) (M. Beloff ed. 1987). This thread in American political thought is derived, of course, from Locke. For a recent discussion of this derivation, see Cohen, Structure, Choice, and Legitimacy: Locke's Theory of the State, 15 PHIL. \& PUB. AfF. 301 (1986).

69. The doctrine evolved from Eastern R.R. Presidents Conference v. Noerr Motor Freight, Inc., 365 U.S. 127, 135 (1961) ("[N]o violation of the [Sherman] Act can be predicated upon mere attempts to influence the passage or enforcement of laws."); UMW v. Pennington, 381 U.S. 657, 670 (1965) ("Noerr shields from the Sherman Act a concerted effort to influence public officials regardless of intent or purpose.").

70. "By a faction, I understand a number of citizens ... who are united and actuated by some common impulse of passion, or of interest, adverse to the rights of other citizens, or to the permanent and aggregate interests of the community." THE FEDERALIST No. 10, at 42 (J. Madison) (M. Beloff ed. 1987). 
founders' reliance on groups' pursuits of self-interest to drive the government.

The diversity in the faculties of men, from which the rights of property originate, is ... an insuperable obstacle to a uniformity of interests. The protection of those faculties is the first object of government. From the protection of different and unequal faculties of acquiring property, the possession of different degrees and kinds of property immediately results; and from the influence of these on the sentiments and views of the respective proprietors, ensues a division of the society into different interests and parties.

... A landed interest, a manufacturing interest, a mercantile interest, a moneyed interest, with many lesser interests, grow up of necessity in civilized nations.... The regulation of these various and interfering interests forms the principal task of modern legislation, and involves the spirit of party and faction in the necessary and ordinary operations of government. ${ }^{71}$

The antifederalist position was explicit in its reliance on representation as a control on factions:

The manufacturers are often disposed to contend for monopolies, buyers make every exertion to lower prices, and sellers to raise them; men who live by fees and salaries endeavour to raise them, and the part of the people who pay them, endeavour to lower them .... [T]hose classes which have not their sentinels in the government, in proportion to what they have to gain or lose, most [sic] imfallibly be rumed.72

The federalists, however, recognized the impracticability of every social interest having its own representative in a legislature of manageable size. ${ }^{73}$ Moreover, they saw the need for individual legislators to represent a broad range of interests rather tlian a specific group:

Is it not natural that a man who is a candidate for the favour of the people, and who is dependent on the suffrages of his fellow citizens for the continuance of his public honours, should take care to inform himself of their dispositions and inclinations, and should be willing to allow them their proper degree of influence upon his conduct? ${ }^{74}$

Thus, republics are superior to direct democracies in requiring the submission of competing interests to the consideration of elected legisla-

71. Id. at $42-43$ (emphasis added). See also 1 THE ReCORDS OF THE FEDERAL CONVENTION of 1787, at 134-36 (M. Farrand ed. 1911) (Madison urges diversity of interests as control on factions.).

72. Letter from the Federal Farmer, No. VII (Dec. 31, 1787), reprinted in THE ANTI-FEDERALIST 77 (H. Storing ed. 1985).

73. "The idea of an actual representation of all classes of the people, by persons of each class, is altogether visionary. Unless it were expressly provided in the constitution, that each different occupation should send one or more members, the thing would never take place in practice." THE FEDERALIST No. 35, at 166 (A. Hamilton) (M. Beloff ed. 1987). For the founders' views of representation, see D. Epstein, THe Political Theory of the Federalist, at 147-61 (1984).

74. THE FEDERALIST No. 35, at 168 (A. Hamilton) (M. Beloff ed. 1987). 
tors who, with greater breadth of view, will be more neutral toward the issue than the competing interests themselves. ${ }^{75}$ Moreover, even where a legislator is not neutral, requiring the concurrence of legislators from an extensive area provides additional control of partisanship. ${ }^{76}$ The federalist view necessarily conceives of representation as a deliberative process that ideally should not respond mecliamically to parochial interests, but should consider the full range of constituents' imterests. ${ }^{77}$

Representation is not, however, sufficient to establish controls on faction. "A dependence on the people is, no doubt, the primary control on the government; but experience has taught mankind the necessity of auxiliary precautions."78 Among these precautions are bicamerahism and the executive veto of legislation, which supply "by opposite and rival interests, the defect of better motives" in representatives 79 and reinforce the deliberative function of government. In recent years, the Court has recognized the centrality of these institutional features to the control of factions, and lias begun to insist on strict adherence to them in the federal legislative process. ${ }^{80}$ State legislatures are subject to even more detailed procedural limitations. ${ }^{81}$

Thus, througli the reconciliation of interests in a deliberative process controlled by representation and various auxiliary cliecks, legislation produces the control of factional dominance that the founders souglit. When, however, legislation takes the form of delegation to an administrative agency under a vague or meaningless standard, the legislative process does not reach a definitive resolution of interests. ${ }^{82}$

75. See THE FEDERALIST No. 10, at 45 (J. Madison) (M. Beloff ed. 1987); see also THE FEDERALIST No. 63, at 323 (A. Hamilton (or J. Madison)) (M. Beloff ed. 1987) (arguing that Senate would represent "cool and deliberate sense of the community," and would sometimes act "as a defence to the people against their own temporary errors and delusions").

76. See The Federalist No. 10, at 45-47 (J. Madison) (M. Beloff ed. 1987).

77. This point is emphasized in Sunstein, supra note 9, at 45-48. See also THE Federalist No. 71, at 366 (A. Hamilton) (M. Beloff ed. 1987) ("When occasions present themselves, in which the interests of the people are at variance with their inclinations, it is the duty of the persons whom they have appointed, to be the guardians of those interests; to withstand the temporary delusion, in order to give them time and opportunity for more cool and sedate reflection.").

78. THE Federalist No. 51, at 265 (A. Hamilton (or J. Madison)) (M. Beloff ed. 1987).

79. Id.

80. See Bruff, supra note 9, at 218-22 (discussing how procedures within Congress, as well as President's veto power, reduce faction); Farber \& Frickey, supra note 9, at 920-21 (describing how Court has invalidated actions taken by Congress in contravention of congressional rules of procedure). For a recent instance of this tendency in the Court, see Bowsher v. Synar, $106 \mathrm{~S}$. Ct. 3181, 3186-91 (1986) (holding that provision of Gramm-Rudman-Hollings Act granting executive powers to Comptroller General, an agent removable only at initiative of Congress, unconstitutionally violates separation of powers).

81. See Farber \& Frickey, supra note 9, at 922-23.

82. See R. Cass, Revolution in the Wasteland: Value and Diverstty in Television 43 (1981). 
Choice of the administrative form over an explicit legal rule permits legislators to shift blame for the costs of regulation and to claim credit for the appearance of its benefits. ${ }^{83}$ The result is not a stalemate, as the founders envisioned, but universal acquiescence in an administratively determined outcome. The Madisonian process of deliberation is thus circumvented, ${ }^{84}$ and the issue is transferred to an administrative process.

3. Administrative Processes. The founders faced nothing like the modern administrative agency and, of course, say nothing directly concerning its legitimacy. They were, however, familiar with administrative abuses during the revolutionary period ${ }^{85}$ and strongly opposed granting significant discretion to executive officers below the cabinet level. ${ }^{86}$ These views are consistent with reliance on republican politics as an assurance of consent.

Some theorists, mcluding Professor Wiley, treat bureaucracy as if it were entirely consistent with democratic pluralisin. ${ }^{87}$ Like legislatures, agencies provide access to affected groups and are subject to a range of cliecks on the exercise of power. Indeed, much of modern administrative law, after the decline of the nondelegation doctrime, is desigued to create in bureaucracy a replica of the representative process with many of its cliecks and balances. ${ }^{88}$ Felaxed standing rules and requirements of broader participation by affected groups ${ }^{89}$ are efforts to mimic legislative representation. The hard look doctrine and the prohibition of ex parte

\footnotetext{
If no one group can command a clear legislative majority for its position, securing legislation that provides detailed solutions to intergroup conflicts can be quite expensive. Creating an agency to implement vague statutory provisions frequently is a solution to this problem. Each contesting group may believe that its interests will be at least as well served by the agency as by the legislature, and the legislators may be more willing to approve the legislative package, since creating the agency arguably gives the appearance of serving genId. eralized consumer interests....

83. M. Fiorina, Legislative Choice of Regulatory Forms: Legal Process or Administrative Process?, 39 PUB. CHOICE 33, 46-52 (1982).

84. Of course, a resolution is reached in the sense that an agency with certain characteristics is created to deal with the issue. To the extent that those characteristics make specific regulatory outcomes predictable, the decision to regulate is not a pure lottery. See infra notes 98-104 and accompanying text.

85. D. Yates, Bureaucratic Democracy 14 (1982).

86. L. WhITE, THE Federalists $448-59$ (1961).

87. See, e.g., R. DAHL, A Preface to Democratic Theory 145 (1956) (noting that vast bureaucratic apparatus set up by American welfare state is part of "normal" political process).

88. See S. Breyer \& R. Stewart, Administrative LaW and RegUlatory Policy 41-43 ( $2 \mathrm{~d}$ ed. 1985) (examines potential conflict between administrative agencies and separation of powers). For a fuller analysis of procedural reform of administrative agencies, see S. BREYER, REGULATION AND ITS REFORM 345-54 (1982).

89. See Bruff, supra note 9, at 210 ("Both Congress and the courts went to considerable lengths to improve opportunities for public participation in agency policymaking.").
} 
contacts are efforts to compel legislative-type deliberation..$^{90}$ Requirements of separation of functions within agencies are efforts to impose a version of the checks and balances placed on the legislative process. ${ }^{91}$ Together, these requirements can be said to foster a deliberative decisionmaking process, ${ }^{92}$ just as the Constitution fosters dehiberation in the process of legislation.

It is demonstrably wrong, however, to say that bureaucratic bargaining is indistinguishable in principle from the legislative process and is equally entitled to deference. Indeed, the very development of these doctrines in recent years reflects a judicial suspicion that agencies are more subject to factional dominance..$^{93}$ In contrast, judicial constraints on legislative action are far weaker. ${ }^{94}$

The replica of the constitutional process that is enforced by judicial review of state administrative action is not equivalent to the true legislative process. The beneficial features of the administrative process described above are less predictably present in state administrative agencies. Furthermore, the federal courts can review state administrative actions only on federal constitutional grounds; such a restriction creates a less adequate check on state administrative processes.

Thus, despite the development of doctrines of administrative law designed to inhibit interest-group dominance, one can make few hardand-fast generalizations about administrative structure, process, and persomiel, particularly at the state level. Certainly, even though simple capture theories have failed to account for much legislative behavior, it is easy to see how capture might occur im legislative processes, where incentives facing decisionmakers are apparent. ${ }^{95}$ In contrast, there is no comprehensive theory of bureaucratic behavior. ${ }^{96}$ The lack of such a theory

90. See Diver, Policymaking Paradigms in Administrative Law, 95 HARv. L. REv. 393, 411-12 (1981); Sunstein, supra note 9, at 63-64.

91. S. BREYER \& R. STEWART, supra note 88, at 128-30.

92. See Reich, Public Administration and Public Deliberation: An Interpretive Essay, 94 YAle L.J. 1617, 1631-32 (1985); Sunstein, Factions, Self-Interest and the APA: Four Lessons Since 1946, 72 VA. L. REv. 271, 282-83 (1986).

93. Indeed, "[t] he constitutional status of administrative agencies has been uncertain precisely because they evade the ordinary constitutional safeguards against domination by powerful private groups." Sunstein, supra note 9 , at 66.

94. Id. at 65-66.

95. See Kalt \& Zupan, supra note 60 , at 279 . For a thorough discussion of the descriptive and presciptive shortcomings of the "strong" interest-group theory of legislation, see Farber \& Frickey, supra note 9, at 883-906.

96. While all commentators seem to agree that bureaucrats do not typically maximize social welfare, there is disagreement over what they do maximize. Compare W. NisKanEN, BuREAUCRACY AND REPRESENTATIVE GOVERNMENT 42 (1971) ("Bureaucrats maximize the total budget of their bureau during their tenure ....") with Peltzman, supra note 2, at 214 ("[The regulator] seeks to maximize net votes or a majority in his favor."). 
does not, however, warrant deference.

Professor Wiley suggests one reason legislators may be captured more readily than administrators.

Certainly the simplest and most direct mechanism of capture-direct payment of money to the policymaker-is easier and less dangerous when the targets are legislators (and their campaigns) rather than bureaucrats. Moreover, appointed bureaucrats are often considered less vulnerable to organized constituent groups than policymakers who face direct electoral pressures. ${ }^{97}$

On the surface, this passage merely repeats the ancient, naïve fiction that administrators formulate policy based upon expertise, imsulated from political pressure. ${ }^{98}$ But the point may be more subtle: to the extent administrators respond to a chief executive with a relatively broad political base, they may respond less to the typical interest-group pressures. The chief executive, with a secure majority coahtion, may ignore the blandishments of even a powerful interest group in order to preserve ideological consistency. That interest group, particularly if it is geographically localized, may indeed find it easier to procure the services of at least some legislators than the services of administrators who are ideologically committed to the chief executive's coahtion.

Such instances are necessarily exceptional, however, because they run counter to the institutional tendencies of the administrative process. Regulators typically are not directly responsive to the chief executive,99 just as they are not directly responsive to the electorate. ${ }^{100}$ The institutional features of regulatory agencies tend to focus attention on a narrower range of interests. Most obviously, legislatures have a far larger number of decisionmakers; this fact by itself inakes them more costly to infiuence. ${ }^{101}$ Legislatures, moreover, are virtually unlimited in their jurisdiction, whereas regulatory agencies are confined by their enabling legislation to a certain range of issues. This jurisdictional limitation carries with it a greater likelihood that the decisionmakers will be interested in

97. Wiley, supra note 6 , at 732 .

98. See J. Landis, The Administrative Process 111-13 (1938). This myth has long since been exploded. See Cutler \& Johnson, Regulation and the Political Process, 84 YALE L.J. 1395, 1402-06 (1975); Jaffe, The Illusion of the Ideal Administration, 86 HARV. L. REV. 1183, 1188-90 (1973).

99. Cutler \& Johnson, supra note 98, at 1401.

100. Some states, however, provicle for the election of public utility commissioners. R. PIERCE, S. Shapiro \& P. Verkuil, Administrative Law and Process § 4.6.1 (1985). Of course, the text is not an argument for fragmenting policy control in this way.

101. See McCormick \& Tollison, Wealth Transfers in a Representative Democracy, in Toward A THEORY OF THE RENT-SEEKING SOCIETY 293, 301-02 (J. Buchanan, R. Tollison \& G. Tullock eds. 1980). As Madison observed, "the representatives must be raised to a certain number, in order to guard against the cabals of a few." THE Federalist No. 10, at 46 (J. Madison) (M. Beloff ed. 1987). 
regulatory outcomes and that the participants in the bargaining process will represent a narrower array of interests.

In addition, normally "appointees to commissions must have the tacit approval of the regulated imdustries." 102 Thus, the appointment process affects the views represented in regulation, narrowing the range of interests that agencies consider. The legislators' more direct representation of the broader electorate is, in general, a safeguard against factional dominance, because it imposes a rehable political compulsion to take account of the full range of interests. ${ }^{103}$

All of these considerations support the conclusion that greater deference is due legislative determinations than administrative ones. Even if the admimistrative process functions according to one of the various models of administrative legitimacy-for example, interest-group imtermediation or net-benefit maximization ${ }^{104}$-when its decision conflicts with the antitrust laws, the federal courts are justified in invalidating the regulation to ensure popular consent. One need not adopt any particular theory of what bureaucrats maximize to see that once they are appointed, their interests will diverge from those of elected representatives. It is fully consistent with traditional conceptions of constitutional, republican government to place greater reliance on more directly representative processes.

What has been said so far does much to refute Professor Wiley's purely economic point that legislatures are as easy to capture as administrative agencies. The economic theory of legislation confirms that many features of the constitutionally ordained legislative process actually inhibit interest-group dominance. ${ }^{105}$ As Professor Wiley points out, there have been instances im which administrators, because of their education, character, and incentives, were not inclined to regulate in the industry's narrow interest. ${ }^{106}$ There are, however, no institutional features of admimistrative agencies that would lead an observer to predict that these instances will be common. While the institutional features of the legislative process clearly "raise the costs of rent-seeking" by interest groups, ${ }^{107}$

102. R. Noll, Reforming Regulation 43 (1971).

103. Bruff, supra note 9 , at 244 , misses this point. Madison, however, made essentially this point in arguing that factional dominance is less likely in a large republic than in a small one, THE FEDERALIST No. 10, at 46-47 (J. Madison) (M. Beloff ed. 1987), and Hamilton made it in arguing for a separation of powers, noting that it is more difficult to secure the agreement of a wide range of interests than a narrow one, THE FEDERALIST No. 73, at 375-76 (A. Hamilton) (M. Beloff ed. 1987).

104. See generally Reich, supra note 92, at 1619-23 (tracing development of the two approaches).

105. Macey, supra note 9, at 247-50.

106. Wiley, supra note 6 , at 732 n.92.

107. Macey, supra note 9 , at 247. 
no such features are predictably present in administrative agencies. Thus, the very fluidity and diversity of agency structures is a basis for concluding that, in general, they will be inore subject to interest-group dominance than legislative processes.

Professor Wiley argues, for exainple, that consumer lobbies "can be just as active before agencies as they are before legislatures." 108 The freerider problein, however, on which Professor Wiley relies so heavily elsewhere, implies that those most directly affected-the regulated industries-will, in general, have the greatest incentive to participate in agency decisions. Consequently, the most consistent flow of information to an agency will be froin the regulated industry. Equally inportant, agencies will be inclined to favor the industry in order to avoid costly appeals of their decisions to courts and legislatures. ${ }^{109}$ All of these characteristics create undeniable incentives for agencies to favor the interests of regulated firms. ${ }^{110}$

A related reason supports the belief that remanding regulatory decisions to the legislature will reduce the frequency of anticompetitive rules. An interest group that is seeking state protection from competition will necessarily prefer a clear legislative preference to a sinuple delegation of the issue to an administrative agency. The clear preference is inore valuable because it is more certain to produce the desired anticompetitive consequences; the agency's behavior, ex ante, will be unpredictable, and ultimately subject to judicial review, which may inipose a public interest constraint on the agency's interpretation of its enabling legislation. Thus, delegation under broad statutory standards occurs only because no interest group lias won in the legislative bargaining process; all groups

108. Wiley, supra note 6 , at 733 11.92.

109. R. NoLL, supra note 102, at 41-42.

110. See T. SOWELL, KNOWLEDGE AND DEcisIons 196-98 (1980) (discussing how these incentives and regulatory agencies' lack of accountability lead to inefficiency and artificially high prices). Ronald Cass has summarized the special advantages that regulated groups have in the administrative process:

By their cooperation or opposition, they can control the amount of resources that will have to be spent by the agency in pursuit of any policy. They are in a peculiarly good position to offer agency members rewards after termination of service with that agency. The power and prestige of the agency itself will not be unrelated to the wealth and infuence of the entities regulated. And, importantly, in bringing their tools to bear on securing the result they desire, these groups have less difficulty than when dealing with the legislature: there are fewer administrative decision-makers (for each group) than there are legislators, and the "constituency" of the administrators is much more limited. The people in most frequent contract [sic] with the administrators, the ones who will complain if not satisfied with agency actions, the ones to whom administrators are, in a praetical sense, answerable, are the people most affected: the groups interested in the regulation, and especially the regulated group.

R. CASS, supra note 82 , at 44 . 
have thus acquiesced in a lottery of potential administrative outcoines. ${ }^{111}$ If one interest group wins in the administrative bargaining process, it n1ay obtain a regulation in conflict with the antitrust laws. If that regulation is invalidated by the federal courts under the Parker doctrine, the issue will be thrown back to the legislative process, and the publicity surrounding the invalidation of the rule will facilitate the organization of opposition to the rule. Because the interest group that won at the administrative level was unable to win in the first instance at the legislative level, it very likely will be unable to win after the rule's invalidation. ${ }^{112}$ At the niargin, it follows that a rule prohibitnig administrative choices in conflict with the antitrust laws will reduce the total nunber of state regulations in conflict with antitrust.

4. Municipal Processes. Of course, the institutions of state government are not limited to legislatures and administrative agencies. It is necessary, therefore, in determining whether deference is proper, to apply the foregonig considerations to any level of government at which critical policy choices are inade. ${ }^{113}$ The focus of the clear-statement

111. Legislative Delegation, supra note 9, at 60-61; see also R. POSNER, supra note 39, at 513 ("[O]ne way to reduce the cost of agreement is to agree on less-to leave difficult issues for future resolution by the courts."). The same logic applies to delegation to agencies.

112. See Farber \& Frickey, supra note 9, at 923-24 (discussing importance of legislative inertia in preventing repassage of legislation after judicial invalidation).

113. A surprising number of Supreme Court cases have dealt with policies adopted by state supreme courts. Most recently, in Hoover v. Ronwin, the Court held that a policy on bar admission standards enacted by the state's supreme court was exempt under its state constitutionally defined legislative authority over the practice of law. 466 U.S. 558, 569 (1984).

It is naive to think that state supreine courts, even those whose members are appointed, are fully insulated from interest-group pressures. Indeed, the kinds of considerations developed in section III of this article, suggest that there is a danger that state courts will enact rules in the interest of the legal profession against the broader consumer interest. The court is composed of lawyers; it is sinall in number; and it is in daily contact with the regulated group. Despite this danger, the extension of the state action exeinption to policies of the state supreme court is necessary. As a coordinate branch of the sovereign exercising a constitutionally prescribed legislative authority, the state supreme court is entitled to deference in its regulatory choices. Courts have traditions of independence and principled decisionmaking that distinguish them from regulatory agencies. While those traditions are largely linited to the decisions of concrete cases, they are closely related to the court's authority over the practice of law.

Hoover reserved the question of whether the state's executive branch may articulate state policy in a way that confers exemption. 466 U.S. at $568 \mathrm{n} .17$. It seens clear, however, that actions of the state's chief executive within his or her constitutionally defined authority would also be entitled to exeinption. Even apart from the chief executive's constitutional status, because of his or her broad political base, the chief executive is less susceptible to dominance by a single interest group than is a legislator or an administrative body. See Lopatka, supra note 3, at 1039-40. In Deak-Perera Hawaii, Inc. v. Department of Transporation, however, the United States Court of Appeals for the Ninth Circuit treated the action of an executive branch departinent as if it were the action of the sovereign, apparently distinguishing the department from independent agencies for purposes of the state action exemption. 
approach on policies formulated by the state as sovereign excludes municipal activities that are not clearly authorized by state legislation from antitrust immunity even in "home rule" cities. ${ }^{114}$ According to Professor Wiley, this distinction undermines a pohicy of local control he discerns in the antitrust laws and is based on a concern with intrastate parochialism that has no place in antitrust policy. ${ }^{115}$ Many of the considerations that justify less deference to administrative choices, however, also apply to municipal choices.

Municipalities are, of course, representative bodies, and this fact may be relevant in evaluating particular delegations. The state action doctrine since Parker has recognized that the articulation of a state policy may be different where the recipient of the delegation is a mumicipality rather than an admimistrative agency. ${ }^{116}$ Legislatures, for example,

The Hawaii Constitution creates the executive as a co-equal branch of the state government and provides for the establishment of departments under the supervision of the governor, HAw. CoNST. art. V, $\S 6$; the Department of Transportation is one such department. HAW. REv. STAT. \$ 26-19 [(1985)]. The Hawaii Constitution charges the governor with "the faithful execution of the laws." HAw. CoNST. art. V, \& 5. In granting Citicorp the challenged lease, the Department of Transportation, as the governor's subordinate, was fulfilling its constitutional duty to execute HAW. REV. STAT. § 261-4 [(1985)], which permits the Department of Transportation to establish and operate airports.

745 F.2d 1281, 1282 (9th Cir. 1984), cert. denied, 470 U.S. 1053 (1985). The court also suggested that the legislature contemplated the establishment of exclusive leases in defining the agency's authority over airports. Id. at 1282-83 (construing HAw. REV. STAT. $\$ 102-2$ ). By this suggestion, the court apparently did not mean that the allegedly anticompetitive policy had been clearly articulated by the legislature; such a finding would have rendered the passage quoted above superfluous. See also Charley's Taxi Radio Dispatch Corp. v. SIDA Hawaii, 810 F.2d 869, 874-75 (9th Cir. 1987) (reaffirming Deak-Perera decision); Flav-o-Rich, Inc. v. North Carolina Milk Comm'n, 593 F. Supp. 13, 16 (E.D.N.C. 1983) (distinguishing agencies through which a state acts directly from regulatory agencies which act like the agency in Midcal); Ajax Aluminum, Inc. v. Goodwill Indus., $564 \mathrm{~F}$. Supp. 628, 632-33 (W.D. Mich. 1983) (holding that "where alleged anticompetitive conduct constitutes the actions of the state, in its sovereign capacity, it is unnecessary to determine whether the challenged conduct was authorized by the state legislature").

The difficulty with the Ninth Circuit's reasoning in Deak-Perera is its equation of a subordinate administrative body with the chief exccutive as a source of statc policy. The reference to executive departments in the state's constitution does not endow them with the authority of the sovereign to announce policy. The mere fact that the administrative agency is nominally within the executive branch of state government does not remove the vast differences between administrative and legislative policymaking. All of the institutional features of independent agencies that render them subject to interest-group control are also present in executive departments. See Huron Valley Hosp., Inc. v. City of Pontiac, 612 F. Supp. 654, 660 (E.D. Mich. 1985), aff'd in part, appeal dismissed in part, 792 F.2d 563 (6th Cir.), cert. denied sub nom. Walker v. Huron Valley Hosp. Inc., 107 S. Ct. 278 (1986); S. BREYER \& R. STEWART, supra note 88 , at 123-26.

114. Community Communieations Co. v. City of Boulder, 455 U.S. 40, $52-57$ (1982); see also City of Lafayette v. Louisiana Power \& Light Co., 435 U.S. 389, 408-13 (1978) (plurality opinion). Home rule cities are cities which, if the local government accepts the terms of the state legislation, reccive a measure of self-governance from state constitutional provisions or legislative action. BLACK'S LAW DictionaRY 66 (5th ed. 1979).

115. Wiley, supra note 6 , at $735,766-67$.

116. Page, supra note 5, at 1120 n.133. 
must distribute authority to the local governments. Very often, these delegations, unlike those to administrative agencies, are made in categorical terms to classes of municipalities. The interest-group dynamics of the legislative process in such instances may not warrant the same concern about single interest dominance. Consequently, it may be that a greater degree of discretion must be included in such delegations to accommodate the variety of circumstances of mumcipalities in the state. ${ }^{117}$ Municipalities are, however, more subject to factional dominance than are state legislatures. As Madison identified: municipalities do not reflect as wide a range of interests as state legislatures and therefore will not provide the same assurances of neutrality. ${ }^{118}$ Moreover, the types of checks imposed to ensure deliberative decisionmaking in the governmental structures vary widely. ${ }^{119}$ These differences have long been recognized in the law. For example, while courts will not invalidate legislative action for irregularities in the process, they have been more willing to do so in the case of municipal action. ${ }^{120}$

Professor Wiley is correct that the demial of antitrust immunity to municipal activities comes at the expense of local autonomy. He is on less firm ground, however, in claiming that this cost is somehow contrary to antitrust policy, particularly since he accepts efficiency as the sole goal of antitrust for the purpose of building his own preemption standard. Even if we were to accept that populist goals are somehow reflected in the antitrust laws, that concession would imply ouly a preference for small economic units; it would say nothing about the sources of regulatory control. ${ }^{121}$ The federahism justification for displacing national norms, based as it is on respect for traditional Madisonian legislative

117. For example, in Town of Hallie v. City of Eau Claire, the Court found the clarity of a delegation sufficient, even though the city was left with the discretion of whether to exercise its authority at all. 471 U.S. 34, 43 n.6 (1985). In Southern Motor Carriers Rate Conference, Inc. v. United States, however, the Court found it significant that the public service commission was not "authorized to choose free-market competition." 471 U.S. 48, 65 n.25 (1985).

118. See generally Rose, Planning and Dealing: Piecemeal Land Controls as a Problem of Local Legitimacy, 71 CAL1F. L. REv. 839, 853-57 (1983) (discussing Madison's view, as expressed in The Federalist No. 10, that local elected government is subject to special interest pressures because of its smail size and lack of variety).

119. For example, state administrative procedure acts typically do not apply to city councils. See H. Linde, G. Bunn, F. Paff \& W. Church, Legislative and Administrative Processes 487 (2d ed. 1981).

120. Lawrence, Private Exercise of Governmental Power, 61 IND. L.J. 647, $683-84$ (1986).

121. The objection to the introduction of extraterritorial parochialism into the state action calculus misses the point. Granted, the problem arises in many contexts, only some of which are within the purview of antitrust. But it is an instance of the kind of political failure that justifies less deference to municipalities. States are likewise subject to a similar kind of political failure when they seek to inpose regulatory costs on other states. In these cases, however, states are subject to a constraint which does not affect municipalities with respect to intrastate parochialism: the commerce clause. 
processes, is far stronger than a generalized preference for local autonomy, which carries with it little assurance of particular processes of lawmaking.

5. Clear Versus Vague Special Interest Legislation. Professor Wiley does not address the distinction made in this section, yet it is crucial to an understanding of the clear-statement approach: legislative choices in conflict with antitrust rules must be clear. This requirement is appropriate on both political and economic grounds: political, because it introduces greater information into the dynamics of interest-group bargaining; economic, because it reduces the mcidence of inefficient regulation. The clarity requirement is thus not merely a proxy for the ultimate issue of legislative intent to displace competition; ${ }^{122}$ it has the independent function of guaranteeing that legislative intent is expressed in a way that ensures adequate information in the political process.

A concern with information is central to the Supreme Court's principal function of reinforcing the process of representation. A primcipal function of the first amendment protection of freedom of speech and press is to ensure an adequate flow of information to the electorate. ${ }^{123}$ Without full information about the activities of government, the process of representation cannot function. ${ }^{124}$

The requirement of clarity in legislative choices also ensures that greater information about the legislative process will be available. Special interest legislation is invariably concealed by a "public interest facade,"125 which can take the form of a delegation of authority to "administrative agencies that [legislators] expect to be captured by interest groups." 126 This tactic is possible because voters have far less incentive to gather information about political choices than about market

122. But see Lopatka, supra note 3, at 1000-02.

123. See, e.g., Buckley v. Valeo, 424 U.S. 1, 14-15 (1976) (first amendment designed to protect free discussion of public affairs and public officials "to assure [the] unfettered interchange of ideas for the bringing about of political and social changes desired by the people" (quoting Roth v. United States, 354 U.S. 476, 484 (1957))); New York Times Co. v. Sullivan, 376 U.S. 254, $296-97$ (1964) (Black, J., concurring) (same). For a theoretical development, see A. MEIKLEJOHN, FREE SPEECH aNd Its Relation to Self-GoverinMent (1948); Schauer, Free Speech and the Argument From Democracy, in Nomos XXV: Liberal Democracy 241 (J. Pennock \& J. Chapman eds. 1983).

124. The protection of promotional advertising has been justified on the ground that it allows a more informed choice concerning regulation of the state's economy. Central Hudson Gas \& Elec. Corp. v. Public Serv. Comm'n, 447 U.S. 557, $579-83$ (1980) (Stevens, J., concurring). But see Posadas de Puerto Rico Assocs. v. Tourism Co., 106 S. Ct. 2968, 2977-80 (1986) (holding that Puerto Rico could restrict advertising of casino gambling).

125. Macey, supra note 9 , at 232.

126. Id. at 263-64. 
choices. ${ }^{127}$

The use of such devices reduces the cost of special interest legislation by inhibiting the orgarnzation of interests in opposition to the bill. ${ }^{128}$ In contrast, compelling clarity in such special interest legislation, reveals the costs of the legislation and focuses the opposing interests' objections. Granted, the clear-stateinent requirement does not prevent supporters from claiming that, despite its distributive effects, the legislation is in the public interest. Clarity about the distributive effects, however, is necessary for an evaluation of the validity of the public interest rationale.

The clear-statement approacl is especially effective in aiding this evaluation after a rule adopted pursuant to legislation has been invahidated by the federal courts because it is inconsistent with the antitrust laws. In such cases, the reasoning of the courts in invalidating the regulations will supply information on which to base opposition to any renewed effort to obtain an explicit preference. ${ }^{129}$

For many of these same reasons, the clear-statement approach will reduce the incidence of special interest legislation in conflict with the antitrust laws. Information plays a central role in the economic theory of legislation, ${ }^{130}$ which teacles that clear special interest legislation is more valuable to interest groups than the concealed variety because it is nore certain to confer the desired benefits. ${ }^{131}$ Clear special interest legislation

127. See generally Mitchell, Efficiency, Responsibility and Democratic Politics, in Nomos XXV: Liberal Democracy 343 (J. Pennock \& J. Chapman eds. 1983) (arguing that "utility-maximizing individuals find fewer incentives for responsible behavior in the polity than in the market").

Awareness of this phenomenon is not new. Madison observed that:

Representative appointments are sought from 3 motives. 1. ambition 2. personal interest 3 . public good. Unhappily the two first are proved by experience to be most prevalent. Hence the candidates who feel them, particularly, the second, are most industrious, and most successful in pursuing their object: and forming often a majority in the legislative Councils, with interested views, contrary to the interest, and views, of their Constituents, join in a perfidious sacrifice of the latter to the former. A succeeding election it might be supposed, would displace the offenders, and repair the mischief. But how easily are base and selfish measures, masked by pretexts of public good and apparent expediency? How frequently will a repetition of the same arts and industry which succeeded in the first instance, agam prevail on the unwary to misplace their confidence?

J. MADison, Vices of the Political System of the United States, in 1 The Founders' Constitution 166, 168 (P. Kurland \& R. Lerner eds. 1987).

128. Macey, supra note 9 , at 232-33, 251.

129. Cf. id. at 256-57 ("[J]udges using traditional metlods of interpretation [such as Frankfurter's practice of narrow construction, as 'judicial blackmail'] impose costs on legislative bargains that lobbyists must reckon with when entering the legislative arena.").

130. See, e.g., Crain \& Goff, Televising Legislatures: An Economic Analysis, 29 J.L. \& EcoN. 405, 407-08 (1986) (discussing economic theory in context of political advertising); Nelson, Political Information, 19 J.L. \& ECON. 315, 320-24 (1976) (discussing political minorities' incentives to collect certain political information and disguise redistributive legislation).

131. Cf. Macey, supra note 9, at 253 ("[T] fuge is the probability that a court will be unable to discern, or will refuse to recognize, the underlying bargain ....."). 
is, however, more costly to obtain in the legislative process because its burdens are more clearly delineated. It follows that a rule prohibiting the hidden variety will reduce the total supply of special interest legislation, because some interests will not be able to afford the greater cost of the explicit preference.

6. The Clear-Statement Requirement in Practice. In addition to his economic objections to the clear-statement requirement, Professor Wiley suggests that the requirement is unpredictable in its application and has been weakened beyond any effectiveness by recent Supreme Court decisions. ${ }^{132}$ The test is inore predictable, however, than any inultistep formula that depends upon such uncertain issues as legislative motivation. Because its focus is on the face of the regulatory statute, all concerned-courts, legislatures, agencies, and interest groups-have before them the raw material of a decision on immunity even before a regulation is challenged. The degree of clarity required is determined not by verbal formulas but by the ultimate issue of whether it is apparent from the statute that the legislature actually inade the decision to adopt the regulatory policy that is assertedly in conflict witli antitrust laws. ${ }^{133}$

This last point also answers Professor Wiley's argument that the courts have not required a significant degree of clarity in the articulation of state policy, particularly since the Supreme Court's decisions in Town of Hallie v. City of Eau Claire ${ }^{134}$ and Southern Motor Carriers Rate Conference, Inc. v. United States. ${ }^{135}$ In Hallie, the Court stated that it was sufficient for exemption that the anticompetitive effects at issue be the "logical" and "foreseeable" results of the statute in question rather than specified or compelled results. ${ }^{136}$ In Southern Motor Carriers, the Court stated that it was sufficient that "tlie State as sovereign clearly intends to displace competition with a regulatory structure"; it need not provide "express authorization for every action that an agency might find necessary to effectuate state policy." 137 Other commentators have noted a greater leniency in the clear-articulation requirement in these cases than in the earlier cases reviving the state action doctrine. ${ }^{138}$ Much of the apparent change, liowever, is the result of the doctrine's maturation; the clear-articulation requirement is the product of a series of cases address-

132. Wiley, supra note 6 , at 736 n.111, 737-39.

133. For an illuminating discussion of the clarity requirement, see Omega Satellite Prods. Co. v. City of Indianapolis, 694 F.2d 119, 125 (7th Cir. 1982) (Posner, J.).

134. 471 U.S. 34 (1985).

135. Id. at 48 .

136. Id. at $42-46$.

137. Id. at 64 .

138. See, e.g., Gifford, supra note 3, at 1275-76; Jorde, supra note 3, at 1415-19. 
ing widely differing forms of state regulation. Understandably, because the policy rationale for the doctrine has been unclear, the relevant concerns in the analysis have only recently begun to be identified.

Although the clear-articulation requirenent inhibits the adoption of anticoinpetitive state regulation, it is not imposed because it does so. It is imposed to ensure the proper functioning of representative processes. It follows that the formal requirements of a clear statement should not be increased simply because to do so would reduce the incidence of anticompetitive regulation. If a requirement does not respond to the needs of the legislative process, it will amount to a practical foreclosure of authority to regulate, ${ }^{139}$ a result inconsistent with the federalisin concerns of the state action doctrine. If it is apparent to all participants in the legislative process that the legislation displaces competition in the market affected, then the pohtical process has worked and exemption should follow. Such a rule, of course, allows legislators to shift responsibility for the costs of regulation, but a doctrine that responds to the competing concerns of both antitrust and federahism cannot confine legislative behavior precisely.

The critical lesson of Hallie and Southern Motor Carriers has less to do with the degree of clarity required than with what is required to be clear. Both cases require a high degree of clarity in the legislative decision to displace competition with governmental action in a particular market; they are far inore lenient in the degree of detail with which the legislation must prescribe the form of the regulatory outcome. This focus on policy is important to an understanding of Hallie's use of the concept of foreseeability. Obviously, all regulatory outcoines are foreseeable in soine sense under the broadest delegations. Under Hallie, the actual decision to displace coinpetition must be clear from the face of the statute; the particular anticompetitive effect must then be foreseeable from that choice. Viewed in this way, Hallie is a particularly obvious application of the requirement. In that case, a city was alleged to have conditioned the sale of sewage treatinent services to neighboring townships on the buyers' acceptance of sewage collection and transportation services. ${ }^{140}$ One of the statutes in question specifically gave the city authority to decide the limits of its sewage service area. ${ }^{141}$ Another statute gave a state agency power to order connection of a city's sewage systern

139. Consider Professor Gifford's proposal for a state action exemption act that would require a detailed statement of costs and benefits for all anticompetitive state legislation. Gifford, supra note 3 , at 1295-97. Under the guise of requiring a clear articulation, such a condition precludes regulation.

140. 471 U.S. 34,39 (1985).

141. Id. at $41-44$. 
to adjoining areas subject to the area's agreement to be annexed to the city. ${ }^{142}$ Although the state agency had made no such order in Hallie, the statutes together demonstrate an unusually clear-cut policy of authorizing cities to impose conditions on the provision of sewage services. ${ }^{143}$

In Southern Motor Carriers, the Justice Department challenged the activities of truckers' rate bureaus in four states, which collectively submitted rate proposals to public service commissions for their approval. ${ }^{144}$ None of the states' regulatory statutes compelled the carriers to use collective ratemaking; three states specifically authorized it, while Mississippi simply directed its Public Service Commission to prescribe "just and reasonable" rates. ${ }^{145}$ Not even Mississippi, however, permitted the commission to choose whether to regulate rates at all; its statute foreclosed the commission from relying on the market to establish trucking rates. ${ }^{146}$ The Court correctly found that the element of compulsion with respect to the truckers' collective ratemaking activities was not required. It was sufficient that the statute directed the commissions in question to eliminate competition through an "inherently anticompetitive rate-setting process." 147 The commissions' choice of the expediency of collective ratemaking in satisfying that policy was not a significantly greater intrusion on federal antitrust policy. ${ }^{148}$

142. Id. at 44.

143. The exception to the "active supervision" requirement articulated in Hallie, id. at 46-47, also does not weaken the clear-statement approach. As I argued in my 1981 article, the active supervision branch of the Midcal standard is inconsistent with the clear-statement approach because it unjustifiably relies on command-and-control regulation as a means of securing state policy. Page, supra note 5, at 1125-36. I also argued, and later studies have confirmed, that public policies may be better implemented by assiguing private property rights than by direct regulation. See, e.g., Cohen \& Rubin, Private Enforcement of Public Policy, 3 YALE J. ON REg. 167 (1985). The legislature can monitor the effectiveness of the policy by "structuring compensation so that it is based upon easily observable data." Id. at 190. For the same reasons, any exceptions to the active supervision requirement do not weaken the clear-statement approach.

The active supervision requirement remains quite healthy. See 324 Liquor Corp. v. Duffy, 107 S. Ct. 720, 725 (1987) (invalidating New York law that required liquor retailers to sell at 12\% markup over prices posted by wholesalers, but permitted wholesalers to sell at less than posted price). As shown by Southern Motor Carriers, however, the degree of supervision required is not great. 471 U.S. at 51 (rates submitted by truckers became effective if public service commission did not schedule hearing).

144. 471 U.S. at 50.

145. Id. at 63.

146. Id. at 65 n.25.

147. Id. at 64 .

148. For an interesting case study of the Civil Aeronautics Board's regulation of airline rates, see S. BREYer \& R. STEWART, supra note 88, at 674-97. One lesson of the study is that the practical difficulties of ratemaking in a structurally competitive market make full hearings on all rates impossible. The Board was thus driven to a mechanical system of rate setting that eliminated competition as completely as any rate bureau. 


\section{The CAPture CRITERION}

The discussion to this point refutes the proposition that clear legislative choices in conflict with the antitrust laws are no more entitled to deference and no more likely to be the result of capture than either administrative choices or concealed legislative choices with the same effect. This arguinent does not address the more general point of whether the concept of capture is a better criterion for governmental legitimacy in the antitrust area than the distinction between legislative and other governmental processes. This, it seems, is Professor Wiley's argument, to which I now turn.

\section{A. Wiley's Four-Part Capture Preemption Test.}

Perhaps in imitation of conventional constitutional opimion writing, which one writer has recently found "obtusively elaborate rather than economical or elegant," 149 Professor Wiley sets up a four-part formula for preemption. State regulation is invahid if it: (1) restrains market rivalry; (2) is not protected by a federal antitrust exemption; (3) does not respond directly to a substantial market mefficiency, identified by the court applying an intermediate level of scrutiny; and (4) is the product of capture. ${ }^{150}$

The stated purpose of this inquiry is to identify the federal preenptive interest. As one reads page after page of elaboration, however, one begins to see that the proposed formula is intended less as a method of analysis than as a rhetorical device for supporting a particular conception of capture as a criterion of legislative legitimacy. 151

Although Professor Wiley justifies the first branch of his test on the ground that it limits the inquiry to state regulation that undermines the policy of the antitrust laws favoring competition, it imposes no real himtation. All state econonic regulation, with a few trivial exceptions, "restrains market rivalry." Thus, unless Professor Wiley means something unusual by that phrase-and nothing he says indicates that he does-the only meaningful branches of his test are the last three.

The second branch - perinitting regulation that falls within a federal antitrust exemption-seems to operate as an affirmative defense. It saves from preemption all state regulation, even the most anticompetitive, that is analogous to exempt federal regulation. While Professor Wiley's interpretation of the exempting effect of federal regulation is quite idiosyn-

149. Nagel, The Formulaic Constitution, 84 Mich. L. REv. 165, 169 (1985).

150. Wiley, supra note 6 , at 743 .

151. In this respect it also resembles modern constitutional opinion writing. See Nagel, supra note 149 , at $190-97$. 
cratic, 152 it is unnecessary to address it, since I contend that Professor Wiley's entire basis for preemption is faulty.

The third branch of Professor Wiley's formula defines conflict with antitrust law not as conflict with any specific antitrust rule, but as conflict with the governing norm of antitrust, economic efficiency. Because efficiency is widely viewed as the sole goal of antitrust, ${ }^{153}$ state regulation not aimed at promoting efficiency is suspect. Thus, the third branch requires that state regulation be aimed at correcting some type of market failure, such as natural monopoly or fraud. ${ }^{154}$ Professor Wiley, drawing from the commercial speech cases, ${ }^{155}$ reasonably proposes an intermediate level of scrutiny.

Professor Wiley recognizes that the efficiency test defines the federal antitrust interest too broadly. To apply an efficiency criterion without modification would result in "antitrust imperialism," burdening state and local government more "than the capture fears that warrant it."156

152. Consider, for example, Professor Wiley's suggestion that the automobile retailers in New Motor Vehicle Bd. v. Orrin W. Fox Co., 439 U.S. 96 (1978) (upholdimg California statute requiring car manufacturers to obtain approval of Motor Vehicle Board before franchising new dealership within ten miles of existing one), may have been covered by the labor exemption. Wiley, supra note 6 , at 746-47.

153. See Wiley, supra note 6 , at $748-51$.

154. See id. at 751-53.

155. Professor Wiley examines three commercial speech cases, and, as Goldilocks might, finds the level of scrutiny in one too strict, $i d$. at 756-59, in another too deferential, id. at 759-62, but in the third-Bates v. State Bar, 433 U.S. 350 (1977)-just right: an "intuitive" form of cost/benefit analysis, Wiley, supra note 6 , at 762-64. The following test emerges:

If all the other criteria were met, the state would have the burden of defending a regulation by showing that the regulation addresses a market inefficiency that typically creates an unavoidable efficiency loss greater than the losses apt to accompany the regulation. The plaintiff would retain the ultimate burden of persuasion and would have an opportunity to rebut the state's defense by showing that the purported market inefficiency is insubstantial or that practical, less restrictive alternatives could accomplish the state's objective.

Id. at 764 .

156. Wiley, supra note 6 , at 765 .

The breadth of an unqualified mandate to preempt inefficient unexempted regulation, taken in its most general form, would logically lead courts to use the Sherman Act's proscription of "restraints of trade" to question any state or local policy that affects resource allocation by altering the rewards to economic activities. That directive jeopardizes a brcathtaking array of state and local policies. Every tax (besides the famous and nonexistent "lump sum transfer") and subsidy becomes suspect. A wide variety of other traditional state and local laws could also become actionable, including market prohibitions on prostitution, marijuana, and baby-selling; restrictions on gun, firework, and drug sales; and limitations such as rent, usury and condominium conversion controls. Each of these policies denies or impedes the satiation of particular human demands that exchange would allow. Under a broad efficiency preemption standard, each would be prima facie suspect.

Id. (citations omitted). Strangely, Professor Wiley illustrates the problem of antitrust imperialism by reference to the two municipal state action cases, $i d$. at 765-68, neither of which was decided on an efficiency preemption standard. His point, apparently, is that any standard that does not focus on capture intrudes unjustifiably on state prerogatives. 
For this reason, Professor Wiley turns to the fourth branch of his test-the capture criterion-to limit the sweep of his test. Under this approach, legislation is the result of capture if "it originated from the decisive political efforts of producers who stand to profit from its competitive restramt," 157 shown by either direct evidence of decisive political efforts or theoretical reasoning from the face of the statute. ${ }^{158}$

\section{B. Ambiguities in the Capture Standard.}

The essence of Professor Wiley's test hies in the interaction of the efficiency and the capture requirements. Although Professor Wiley offers only a single definition of capture, he states that it may be proven in two ways: directly, by evidence of political support by an interested group, or indirectly, by inference from the face of the statute. ${ }^{159}$ These two methods of proof imply very different conceptions of capture. A moment's reflection, however, shows that only the indirect method can have any practical significance.

1. Direct Proof of Capture. The inost obvious objection to relying on direct proof of capture is that the evidence will not be available. State legislative histories, such as committee reports and floor debates, are rarely maintained. Still less common are records of municipal and administrative deliberation. Thus, even for recent regulations it would be uulikely that adequate evidence of interest-group support would be present; for older regulations, it would be impossible.

Even if standard legislative histories are present, they could not establish capture in its only meaningful sense: the acquisition of favorable legislation through the exercise of raw political power. Professor Wiley states that "the determination of whether producer political participation was 'decisive' is simple and straightforward in many situations in which the only political support for a market restraint came from a narrow interest group." 160 This passage appears to say that the mere lobbying presence of a single group is sufficient to establish capture. This interpretation is consistent with his statement that "[s]ome regulation, despite its possibility of capture, nevertheless seeins desirable. ... Producers inight be the first to identify a problem in their market and might be instrumental in designing a regulatory response that benefits consumers as well as the industry." 161 Professor Wiley illustrates his point with the following

157. Id. at 743 .

158. Id. at $770-72$.

159. Id. at 769-73.

160. Id. at 770 .

161. Id. at 741 (citation omitted). 
remarkable hypothetical:

Suppose, for instance, that the makers of firearms lobby to ban machine gun sales for fear that public backlash against use of automatic weapons, if delayed and broadened, might outlaw all gun sales. Manufacturer support-even if solely responsible for the regulatory ban-should not be sufficient to condemn the restraint on competition. ${ }^{162}$

The difficulty with this reasoning is that the mere fact that consumers did not lobby cannot establisli that legislators did not weigl the consumer interest politically. ${ }^{163}$ Indeed, a rational legislator cannot ignore the consumer interest. ${ }^{164}$ In Professor Wiley's fantastic lyypothetical, for example, no observer could say based on the legislative history that the ban on machine guns was the result of capture by weapons manufacturers. The same factors that lead Professor Wiley to say that the ban "seems desirable" and "benefits consumers" may have been the decisive factor for legislators. Similarly, the fact that publishers and authors benefit from and support copyriglit legislation does not establish that such legislation is the result of capture; it is at least equally likely that legislators accepted the argument tliat clearly defined property rights are necessary to assure adequate incentives to produce public goods such as literary works. ${ }^{165}$

Pressure groups always have contended that their interest and the public's interest coincide, and in some instances the legislature has agreed.

Seldom in American history did the goals of private groups form a perfect identity with those of the rest of society, but seldom a perfect antithesis, either. Instead, sets of goals overlapped, now finely, now amply. Within the zones of overlap, private groups plausibly claimed service to society and "capture" coexisted in fleeting calm with "public interest." 166

As Edward Banfield has written, pohtical infiuence may be based upon rational persuasion just as it may be based upon deception, coercion, or positive or negative inducement. 167 Although Professor Wiley's test appears to make no distinction among these forms of influence, laws en-

162. Id. at 741 n.136.

163. Farber \& Frickey, supra note 9 , at $908-09$ (discussing difficulties in attempting to identify special interest regulation).

164. See Peltzman, supra note 2, at 214; Posner, Taxation by Regulation, 2 BeLL J. ECoN. \& MGMT. Sci. 22 (1971).

165. For other illustrations, see Farber \& Frickey, supra note 9, at 909-10 (discussing minority set-aside programs and nuclear regulation).

166. McCraw, supra note 31, at $\mathbf{1 8 2 .}$

167. E. Banfield, Political Influence 4-5 (1961). 
acted in response to public welfare arguments inay be the result of political representation of a broader range of interests.

Professor Wiley furtlier demonstrates his confusion on this point when lie states that '[t]lie 'decisiveness' question grows inore difficult and speculative when political support is mixed. Even so, the inquiry remains theoretically coherent, analytically tractable ... and analogous to other questions that courts routinely settle." $168 \mathrm{He}$ supports this assertion witl a footnote in which lie analogizes "direct" proof of capture to the proof that an employer's misrepresentations impermissibly influenced NLRB representation elections. ${ }^{169}$ Presuinably, le is suggesting here that evidence of testimony in support of legislation by a producer can establish capture just as an employer's factual imisrepresentations can establish improper influence.

In the first place, it is surprising that Professor Wiley would recominend as "tractable" a standard so notoriously ad hoc and unpredictable in labor law. ${ }^{170}$ Second, since imisrepresentation is not an element of his definition of capture, it is difficult to see what bearing the NLRB standard has on legislation. Finally, the relationship between employers and employees in a representation election is, to put the matter mildly, not comparable to the relationship between lobbyist and legislator in legislative bargaining. Material misrepresentations by employers are presuined to influence an election because of the einployers' position of power and the einployees' unusual susceptibility. As dubious as this presumption is in the labor context, it lias no application to statements of lobbyists to legislators. Sucli stateinents can imply only that the legislators were aware of a speaker's position, not that the legislators acted to benefit the speaker.

Soine studies have attempted to isolate the economic and ideological determinants of legislative voting on individual issues. ${ }^{171}$ If it were possible to define, witl confidence, the economic interest variables for each legislator, it miglit also be possible to identify statutes in whicl those variables were strongly correlated with legislative outcomes. Sucli results presuinably would be circumstantial evidence of capture. The kinds of data that Professor Wiley relies upon, lowever, would be probative of notling.

168. Wiley, supra note 6 , at 770 .

169. Id. at $770 \mathrm{n} .268$.

170. See A. Cox, D. Bok \& R. Gorman, Cases and Materials on Labor Law 159-60 (1977) (Decisions concerning employers' freedom of expression inspire continuing debate.).

171. E.g., Kau \& Rubin, Self-Interest, Ideology, and Logrolling in Congressional Voting, 22 J.L. \& ECON. 365 (1979). 
Professor Wiley's criterion of decisiveness is subject to similar objections; it appears to sweep in an indeterminate number of laws. He says that '[s]pecifying 'decisiveness' as the relevant standard solves the problem of mixed political support-what Bruce Yandle has called the issue of 'bootleggers and Baptists'-by screening from preemptive review regulations that lack a crucial element of capture."172 Professor Wiley apparently does not mean that mixed pohtical support precludes capture, since in a passage already quoted. he suggests that the issue in such cases is "more complex" than in those in which political support is unitary. ${ }^{173}$ Suppose, for example, that Baptists support a Sunday closing law and that restaurant operators oppose them. If bootleggers support the law, and, because of their support, the law passes, are such laws the product of capture? If so, is all economic regulation the result of capture, since some interest group's support typically plays a "decisive," if nrarginal, role? Additionally, what is a court to do with the case of "logrolling," in which one group receives a pohtical favor to compensate for a different group receiving a favor? In what respect is pohtical support of a single group decisive in such circumstances?

Enough has been said to show that Professor Wiley's standard for direct proof of capture is impractical and excessively broad. Nor is it sufficient to say that legislation may be saved by the third branch of Professor Wiley's test: proof that it is aimed at a substantial market failure. As Professor Wiley himself recoginizes, the efficiency standard, which forecloses from legislative consideration every public interest concern but one, threatens to invalidate virtually all of state regulation. The tenuous "decisive pohtical support" 11otion of capture, particularly in its suicidal "direct proof" form, is inadequate to justify forcing "state and local authorities through a costly and demeaning defense of their myriad regulatory policies." 174

2. Indirect Proof of Capture. Capture, both as a practical matter and as a matter of principle, cannot be established without consideration of the effect of the statute. Perhaps recognizing this, Professor Wiley states that capture may be shown where "the challenged regulation's terms evince a pattern of effects that make its heritage of capture obvious." 175 In this case, he says, the fact that the legislation benefits a particular group is inadequate to support an inference of capture; it is

172. Wiley, supra note 6 , at 770 (footnote omitted).

173. Supra note 168 and accompanying text.

174. Wiley, supra note 6 , at 765 .

175. Id. at 770 . 
necessary to exclude independent public interest rationales. ${ }^{176}$ The issue of capture, then, becomes primarily a matter of inference from the face of the statute-what Professor Wiley calls indirect proof of capture.177 Here, a court applies economic reasoning to determine if the most likely explanation for the cliallenged regulation is that it benefits a particular producer interest. If a court finds that the most likely reason for the legislation is to enrich a simgle producer group, the capture is prima facie established.

Defendants should have the opportunity to rebut this inference of capture with evidence supporting other explanations of political origin. Rebuttal evidence, however, should be of actual legislative influence or consideration, rather than simply creative speculation by the state attorney general at the time of suit, if it is to rebut a highly suggestive facial pattern of capture effects. Cases of doubt should be decided against the plaintiff's preeniptive challenge. ${ }^{178}$

Of course, the last sentence in the above passage cannot be meant seriously. All cases, particularly those imvolving the application of a test as general as Professor Wiley's, involve some measure of doubt. Clearly, all these cases cannot be decided agamst the plaintiff's preemptive cliallenge. If we disregard the last sentence of the passage, the capture requirement becomes a lieiglitened form of rationality review, indistinguisliable from Lochner-era economic due process review, altliougli limited to cases of competitive restraints in favor of producers. ${ }^{179}$ This version of the capture requirement renders the third branch of Professor Wiley's preemption test, which requires an efficiency rationale for legislation, redundant as a practical matter; legislation that lias no public interest rationale will perforce also liave no efficiency rationale. ${ }^{180}$ Professor Wiley seems to recognize capture as the only mquiry of consequence, when he states that its function is to select "those cases in which the federal interest in economic efficiency is at its maximum and the state

176. Id. at $771-72$.

177. Id. at 769-72.

178. Id. at 772 .

179. Professor Wiley is admirably frank in his recognition of this identity, using a Lochner-era case, Louis K. Liggett Co. v. Baldridge, 278 U.S. 105 (1928), overruled, North Dakota State Bd. of Pharmacy v. Snyder's Drug Stores, 414 U.S. 156 (1973), to illustrate the capture test and justify the approach in spite of the poor reputation of Lochner-style review. Wiley, supra note 6, at 770-71.

180. The only exception to this statement flows from the apparent restriction of public interest rationales in the capture test to those that were actually considered by the legislature. The efficiency test would allow post-hoc justifications. Thus, legislation that is the result of capture may later be found efficient. This anomaly may have occurred in the case of fair trade legislation, which was certainly enacted to benefit small retailers, but has later found economic support. See S. OPPENheim, G. Weston, P. Maggs \& R. Schechter, Unfair Trade Practices and Consumer Protection 3-5 (4th ed. 1983). 
and local interest in self-governance is at its minimum."181 This passage implies that the capture test does indeed supersede the efficiency test, selecting only the most inefficient forms of regulation, while simultaneously identifying the cases in which the state's political process is defective.

\section{Capture and Legitimacy.}

The use of capture as a criterion for preemption is subject to two objections. First, it is highly doubtful that capture is an indicium of illegitimacy in a constitutional democracy: legislation that is the result of capture cannot be distinguished in principle from any other redistributive legislation. Second, even if we were to accept the distinction in principle between capture and other types of legislation, it should not be the role of the courts to enforce the distinction as a criterion of legitimacy.

1. Capture and Legislation. Professor Wiley's argument depends upon his assertion that the existence of capture is a criterion of illegitimacy in legislation. He recognizes that the mere inefficiency of legislation-its failure to coincide with the prescriptions of welfare economics-is an inadequate basis for preemption under federal antitrust law because in a federal, republican systen, the states should have discretion in the choice of legislative means to deal with social and economic problems, and these means presumably include inefficient legislation. ${ }^{182}$ Capture, however, according to Professor Wiley, supplies the necessary basis for preemption because it removes any ground for deference to the state's choice. Legislation that is the result of the naked political strength of a special interest is illegitimate.

As we have seen, it is an essential feature of the founders' conception of a republic that governinent will be driven by interest groups that pursue their self-interest. It is also unavoidable that some groups will be more effective in the political process than others and thus will be better able to obtain legislation in their interests. This conflict between interest groups poses important dangers to the public interest, dangers that the institutional structures of government are desigued to ameliorate, principally by raising obstacles to the passage of special interest legislation. Legislation that survives the gauntlet of these structures may be good or bad in an economic or moral sense. It may be invalid if it violates constitutional rights or otherwise conflicts with higher legislative norms. Leg-

181. Wiley, supra note 6 , at 769 . See also id. at 764 (stating that the capture criterion "focuses on those state or local regulations most likely to undermine market competition seriously, and it limits preemption to instances of state political decisionmaking that deserve less deference").

182. See id. at 765 . 
islation is not, however, illegitimate by virtue of the fact that one interest group has won in the legislative process. What has been said of rationality review in the constitutional context is applicable here: "Because no one seems to think it improper for interest groups to influence the legislative process, it cannot be right to invalidate legislation just because it was procured by an interest group." 183 Rationality review, in other words, is inconsistent with the notion of a legislature with plenary power to answer or ignore the needs of its constituents. ${ }^{184}$

Note that the foregoing point does not depend upon a pluralist conception of the legislative process. Even if one accepts, as I do, a deliberative conception of that process, ${ }^{185}$ it does not follow that legislation that mechamically responds to private interests is illegitimate. The deliberative norm is relevant only in the design of the legislative process; legitimacy is defined as the legislation having followed the proper processes.

The weakness of capture as an indicium of legitimacy is apparent in Professor Wiley's limitation of the concept to producers. He claims that the basis for federal suspicion of the state political process is the presence of the free-rider problem-the lack of an adequate incentive for pohtically effective opposition to anticompetitive legislation. He then concludes, without explanation, that only producers stand to benefit from this "systematic problem." When renters obtain legislation imposing rent control, he argues, we cannot term what has happened capture, because to do so would be to "dilute the capture element until it means little more than 'political success.' "186 There is, however, no reason in principle to distinguish rent control from capture by producers. It is the success of a small number of incumbent renters in imposing a regime of price restraints that crudely transfers wealth from landlords to thein and drastically reduces the supply of rental property. They are able to do this only by controlling the supply of available information to policymakers and exerting their disproportionate influence in the political process. The vast number of those adversely affected-renters who are unable to obtain rent-controlled apartments-are unable to organize in opposition largely because of the free-rider problem.

Admittedly, this logic equates capture with political success in obtaining redistribution of wealth, but it does so because the two are indis-

183. Posner, supra note 9, at 285. See also R. POSNER, supra note 39, at 586-87 (noting it is characteristic of democratic legislative processes to be influenced by politically effective interest groups).

184. Linde, Due Process of Lawmaking, 55 NEB. L. REv. 197, 229-30 (1976).

185. For a development of the pluralist/deliberative distinction, see Sunstein, supra note 9, at $38-48$.

186. Wiley, supra note 6 , at 768 . Wiley restates this argument in Wiley, supra note 8 , at 171-72. 
tinguishable. One of government's principal functions is to transfer wealth. It does so only because a group has been politically successful, sometimes by outright coercion, other times by arguments that the transfer is morally necessary. Professor Wiley attempts to prevent his concept from swallowing all redistributive legislation by limiting it to redistribution in favor of producers. While this distinction may isolate certain types of legislation that he finds unwise, it does not lend coherence to capture as a criterion of legitimacy.

2. Capture, Legislation, and Judicial Review. The notion of legitimacy of legislative action has meaning primarily im the context of judicial review. When viewed in this context, capture becomes even less plausible as a measure of legitimacy. Legislation that is the result of producer capture is not illegitimate $\mathrm{m}$ the sense of warranting judicial invalidation, for two reasons. First, capture is not the kind of political defect that warrants the countermajoritarian step of judicial intervention in democratic processes. Second, the issue of capture is beyond the power of courts to determine.

a. Majoritarianism and judicial review. During the debates over the ratification of the Constitution, Thomas Jefferson proposed that a prohibition on legal monopohes be included im any federal bill of rights. ${ }^{187}$ His longtime associate Janes Madison responded:

Monopolies are sacrifices of the many to the few. Where the power is in the few it is natural for them to sacrifice the many to their own partialities and corruptions. Where the power, as with us, is in the many not in the few, the danger can not be very great that the few will be thus favored. It is much more to be dreaded that the few will be unnecessarily sacrificed to the many. ${ }^{188}$

The essential insight of this passage is that constitutional limitations in a republic are essentially countermajoritarian devices to protect the interests of minorities. The founders were, of course, opposed to rule by the few over the inany-as, for example, in monarchies, or even in states where the franchise is artificially restricted. But in a republic, where the many have the political wherewithal to protect their own interests in the electoral process, there is no need for constitutional-that is, nondemocratic, judicially enforced-inhibitions.

Does the insight of capture theory change this logic? It establishes beyond dispute that soine interests will have advantages im the pohtical

187. Letter from Thomas Jefferson to James Madison, (July 31, 1788), reprinted in 1 THE FouNDERS' CoNSTITUTION, supra note 127 , at 476.

188. Letter from James Madison to Thomas Jefferson (Oct. 17, 1788), reprinted in 1 THE FOUNDERS' CONSTITUTION, supra note 127 , at 478. 
process that will give them disproportionate influence. These advantages may result in the enactment of legislation that benefits the few over the many. It may be, then, that "Madison did not sufficiently reckon with the advantages that factions receive from the incentives in our system." 189 Those advantages are not, however, of the kind that justify judicial foreclosure of a particular legislative outcome.

Mmorities face an intrinsic obstacle in the majoritarian political process that warrants special judicial protection. Capture, which imvolves an advantage of the few over the many, is not of this type. Nevertheless, the courts are sometimes concerned with advantages that the few may have over the many: the advantage, for example, conferred by a grossly malapportioned legislature, in which a few have disproportionate representation, or by a legislature elected under an artificially restricted franchise, for which only a few may vote at all. The latter types of political advantages certainly warrant judicial intervention, not to foreclose particular outcomes but to correct the flaws in the pohtical process. Analogously, the advantage conferred by the free-rider problem on certain small groups may justify judicial action to mcrease the amount of information in the pohtical process. It does not warrant absolute foreclosure of a political result im favor of a particular group, however, because the ultimate check of majoritarianism is in place.

Far from reinforcing the process of representation, judicial foreclosure of a legislative outcome undermmes it by removing the incentive for the electorate to make an independent evaluation of the wisdom of legislation. It is far more consistent with the proper role of a court in a democracy to assure that critical decisions are made by fully imformed legislative processes.

b. Institutional competence. Even if the courts should, in principle, invalidate laws that are the result of capture, they are institutionally incapable of distinguishing such laws from those that are the result of a conception of the public interest. Professor Wiley anticipates the argument that courts are inappropriate bodies to decide the capture question. ${ }^{190} \mathrm{He}$ fails, however, to address the central issues. He first contends that courts, because they have access to the economic literature and the testimony of expert witnesses, are as capable of forinulating antitrust policy as legislatures. ${ }^{191}$ The only validity of this point lies in the formulation of substantive rules of antitrust liability under a criterion of economic efficiency. It has no application to the proposed capture pre-

189. Bruff, supra note 9, at 215.

190. Wiley, supra note 6 , at 776-79.

191. Id. at 778 . 
emption standard, where, by definition, the issue is not simply the efficiency of an arrangement, but whether a deniocratically enacted regulatory schenie is designed siniply to transfer wealth to a producer group or to accomplish sonie public-regarding purpose, economic or otherwise.

In the unadorned antitrust case, the court need only consider the economics of the issue; indeed, the efficiency standard is justified largely because courts are inappropriate bodies to decide popuhist, redistributive issues. ${ }^{192}$ In the capture preemption case, the court nust determine niore than merely that the regulation transfers wealth from one group to another. ${ }^{193}$ It also inust find that the motivation for a regulatory enactnient is siniply to transfer wealth to a regulated group rather than to advance some conception of the public interest. The fact that the enactment is inefficient is inconclusive, because the legislature is free to accept any conception of the public interest.

The objections to judicial inquiries into legislative motivation are well developed in the literature. ${ }^{194}$ Professor Sunsten 1 has summarized these arguments:

The job of ascertaining the extent of factional control over legislative processes involves unmanageable inquiries into legislative inotivation and the drafting process. Even individual legislators almost always act on the basis of inixed motivations. Conceptions of the public good and the desire to be reelected are inseparably intertwined. The problem becomes truly intractable when the issue is the "motivation" of a multimember decisioninaking body. In such circumstances, the notion of motivation becomes incoherent; another basis for analysis is necessary. Finally, there is little reason to believe that courts are themselves immune from "ideology." 195

Furthermore, because courts must decide the issue in a concrete case, they are denied the broader perspective of the legislative process for evaluating the overall rationality of legislation. ${ }^{196}$ In practice, inquiries into legislative purpose in constitutional law tend to be extraordinarily defer-

192. R. Bork, The ANTITRust Paradox 81-89 (1978).

193. The wealth redistributive effect of regulation is so ubiquitous that one commentator has termed it the "Iron Law of Public Policy." R. LeONe, Who Profits: WinNERs, Losers, AND GOVERNMENT REgULATION 3 (1986).

194. See, e.g., Ackerman, supra note 9; Ely, Legislative and Administrative Motivation in Constitutional Law, 79 YALE L.J. 1205 (1970); Colloquium, Legislative Motivation, 15 SAN DIEGO L. REV. 925 (1978); see also Macey, supra note 9, at 228 (It is "impossible for judges to reconstruct the complex array of motives that prompted the passage of a particular statute.").

195. Sunstein, supra note 9, at 77. Professor Sunstein outlines a response to these objections that he concedes is inadequate. He recognizes that direct determination of motivation is impossible and must be replaced by a tractable inquiry to serve as a proxy. Id. at 79-80. Professor Wiley does not recognize this. As a result, it is impossible to address the proxy he would use.

196. Bruff, supra note 9 , at 226. 
ential, primarily because the courts recognize the difficulties of the inquiry. 197

Taxicab regulation is often cited as a pure case of capture. ${ }^{198}$ It is an unusually simple inatter to measure the monopoly rent conferred by this kind of regulation by observing the transfer value of medallions. ${ }^{199}$ Soine schemes of regulation even assigu a dominant inarket share to firms by name. ${ }^{200}$ Would all of this estabhish capture under Professor Wiley's proposed test? The answer is no.

Since every economic policy decision produces transfers of wealth, it is always possible to infallibly relate pohtical outcoines to distributional impacts. This approach, in fact, leaves open the question of whether the behavior and results we observe in the pohtical arena are the product of something more than the parochial, pecuniary interests of affected parties. ${ }^{201}$

In other words, there may be ideological or broader political motivations for regulation independent of its distributive effects. Indeed, studies tend to show that economic interest variables are by no means the exclusive determinants of voting on specific issues. ${ }^{202}$ Because of the separation of "ownership" by constituents and "control" by legislators, legislators have a measure of ideological independence. ${ }^{203}$

Even in the case of taxicab regulation, there is no shortage of public interest arguments. ${ }^{204}$ In Chicago, in the midst of a recent political crisis

197. "Inquiries into congressional motives or purposes are a hazardous matter. ... What motivates one legislator to make a speech about a statute is not necessarily what motivates scores of others to enact it, and the stakes are sufficiently high for us to eschew guesswork." United States v. O'Brien, 391 U.S. 367, 383-84 (1968).

198. See generally Kitch, Isaacson \& Kasper, The Regulation of Taxicabs in Chicago, 14 J.L. \& ECON. 285 (1971).

199. See id. at 346 n.245 (value of licenses in several U.S. cities). It is not, of course, typically this easy to measure the effects of regulation.

The classic public interest justification for regulation is market failure. Whatever its public interest justification, regulation vigorously distributes private benefits and costs. Except in extreme instances, therefore, it is not practicable to categorize it as public or private goods legislation. Indeed, the distributional effects of regulation may be substantially more difficult to isolate than those of a money subsidy.

Bruff, supra note 9, at 215.

200. Kitch, Isaacson \& Kasper, supra note 198, at 286-88.

201. Kalt \& Zupan, supra note 60 , at 280 .

202. E.g., id.

203. Id. at $282-84$.

204. The same arguments recur throughout the history of the industry. See Kitch, Isaacson \& Kasper, supra note 198, at 302-16, 318; FTC Praises New York Taxicab Bill, but Urges Elimination of Restrictions, 51 Antitrust \& Trade Reg. Rep. 936-37 (1986); FTC Staff Urges More Taxis for San Francisco, 51 Antitrust \& Trade Reg. Rep. 897 (1986). For a recent, formal argument that taxicab regulation may be an efficient means of economizing on search and transaction costs by enforcing average prices, see Gallick \& Sisk, A Reconsideration of Taxi Regulation, 3 J.L. Econ. \& ORG. 117 (1987). 
over taxicab reform, ${ }^{205}$ the popular press coverage included dire reports of the disastrous consequences of free taxicab competition. ${ }^{206}$

Confronted with such a record supporting taxicab regulations, could a court say that regulation in a given city was the result of capture and thereby compel deregulation? To do so would require the court to find that legislators either did not accept the public interest evidence, and were actually motivated by a desire simply to benefit taxicab operators, or if they did accept the public interest evidence, were motivated by a kind of false consciousness which can be disregarded. Barring an admission by counsel, tliere would be no basis for the first finding. The leading study of taxicab regulation found that a proposal for a cap on medallions in Chicago was rejected politically in 1932, but was accepted two years later because of an ideological change in national politics: the passage of the National Industrial Recovery Act persuaded city officials of the public benefits of restricted competition. ${ }^{207}$ The second finding would be nothing more than the adoption of efficiency as a criterion for preemption, a result that Professor Wiley explicitly escliews. All of this supports the generalization that "all statutes have an ostensible public-interest justification, and even where the fig leaf is thin it is difficult for the courts to see through it."208

Even if a principled court were able to find capture in one instance of taxicab regulation, its finding would not establisli capture in instances in which the regulatory record included more public interest arguments. In other words, the capture preemption test will only dictate preemption in the crudest cases; those witlı a inore convincing public interest record

205. Chicago's system of taxicab regulation was upheld under the Parker doctrine in Campbell v. City of Chicago, 1987-1 Trade Cas. (CCH) \& 67,633 (7th Cir. 1987).

206. Gorman Gilbert, head of the New York Taxi and Limousine Commission, was quoted as follows:

My advice to your city would be to look very, very skeptically at the alleged benefits of open entry .... The theoretical argument is that there will be more service of a better quality. Rather than rely on that argument take a look at those cities that have tried it and see if that's really what you want.

Chicago Tribune, June $29,1986, \S 5$, at 1 , col. 4. The press reported that deregulation in Atlanta "glutted the market and brought loud complaints from passengers about inexperienced drivers, price-gouging and poor quality cabs." Id. $\S 5$, at 4, col. 1 (remarks of N. Radakovich). Atlanta's city attorney, who has testified against taxicab deregulation in several cities, stated that "[p]olicing was a terrible problem during deregulation and remains a terrible problem because [Chicago] still $\mathrm{ha}[\mathrm{s}]$ too many cabs [after reimposing a cap on the number of cabs].... There were no benefits that I could see." Id.

207. Kitch, Isaacson \& Kasper, supra note 198, at 321.

208. R. Posner, The Federal Courts 271 (1985). See also R. CASS, supra note 82, at 42 (discussing use of complex legislative regulation as opposed to cash subsidy to hide industry's benefit and give appearance of social good); Linde, supra note 184, at 213 ("The almost invariable impulse is to credit the lawmaker with aiming at some higher social goal, no matter how erratic this makes his course toward it appear."). 
will escape. Such an approach is hardly an appropriate means of protecting federal antitrust pohicy.

The Court's experience in similar enterprises is not encouraging for Professor Wiley. The requirement that state economic regulation be rational is at best "underenforced," 209 largely for the reasons developed here. It is unlikely that capture preemption review would fare better. In a concurrence in Cantor v. Detroit Edison Co., 210 Justice Blackmun attempted something very similar to Professor Wiley's approach, suggesting a "rule of reason" to determine the economic validity of state economic legislation. In applying his test retrospectively to the facts of Parker, however, he found the prorate scheme valid as a way of avoiding wild fluctuations in the supply of raisins. ${ }^{211}$ This dubious-if not absurd-conclusion suggests that any direct judicial examination of the wisdom of state regulatory schemes, regardless of its stated formulation, is likely to be highly deferential and thus meffective in accomphishing its stated purpose. ${ }^{212}$

Of course, $m$ the Lochner era, the Supreme Court sporadically enforced a form of strict scrutiny of state econoumic legislation under the due process clause. Professor Wiley exphicitly connects his proposed test to the analysis used in these cases. ${ }^{213}$ The Court, however, is as unlikely to adopt this form of review im the state action context as it is to revive the Lochner standard as a matter of constitutional law.

Professor Wiley attempts to avoid the fatal equation of his test with Lochner by observing that economic due process, as a constitutional doctrime, forecloses pohitical control of the economy. Under his proposed test, courts are carrying out a congressionally ordained function that, in turn, is subject to ultimate congressional control.214 It is, however, wholly fictitious to say that any shape the state action doctrine takes is prescribed by Congress. Even in its apphication to private conduct, the Sherman Act is so open textured and the legislative history so vague, that any standard the Court adopts is ultimately a judicial creation. The efficiency criterion, which excludes popuhist, redistributive concerns, has been justified largely by notions of judicial competence. The state action

209. Sunstein, supra note 9 , at 55 .

210. 428 U.S. 579, 610-12 (1976) (Blackmun, J., concurring).

211. Id. at 613 n.5.

212. Professor Wiley describes the Blackmun approach in favorable terms, criticizing it only for a point that does not distinguish it from his own. The Blackmun approach, Professor Wiley says, is "indeterminate because states always have some reason-presumably beneficial in their judgmentfor their challenged action." Wiley, supra note 6, at 743 n.143. For the same reason, courts will be unable under Professor Wiley's test to determine if capture is the most likely origin of the regulation.

213. See id. at $770-71,779$.

214. See id. at 779 . 
doctrine is even more purely a judicial invention as Congress probably never contemplated an application of the antitrust laws to state regulation. ${ }^{215}$

Thus, in adopting the capture preemption standard, the Court would be imposing its view of correct policy on the states as it did in Lochner. The Court's adoption of the efficiency criterion in antitrust cases is based largely upon judicial incompetence to decide redistributive questions; that criterion does not cast doubt on the competence of state legislatures to decide similar issues. The fact that Congress remains free to change judicial choices in these cases ${ }^{216}$ does not change the antidemocratic quality of this judicial role: inost issues arismg under the state action doctrine are primarily local im their effects, both positive and negative. Such issues will not command congressional attention regardless of their merits. There vill remain, by virtue of congressional inertia and lack of interest, a wide range of cases in which judicial choice supplants popular choice to exactly the same degree as in the Lochner era.

\section{Regulation and Collective Action}

Nothing in uny argument up to this point denies the existence or significance of capture. As several recent studies have shown, the courts must take account of interest-group dynamics in formulatimg doctrine that will affect legislative and administrative processes. ${ }^{217}$ The clearstatement approach is merely one example of this awareness of the problems of capture. It recognizes that regulations in conflict with antitrust laws may have been the result of capture, although it is also possible that they are aimed at some form of market failure or antitrust failure. The clear-statement approach addresses the problen, however, not by attempting to distinguish the inotivations for regulation, but by assuring that regulations that conflict with antitrust are adopted through processes that are unost likely to produce a Madisomian reconciliation of interests.

The clear-statement approach, because it recognizes the domains of legislative and judicial competence, is inore effective in addressing the problem of capture than the direct, substantive approach proposed by Professor Wiley. The clear-statement approach, however, does require a determination of whether the regulation in question actually conflicts with antitrust laws. This issue may be perplexing: governmental institutions may accomplish ends similar to private restraints by very different

215. Slater, Antitrust and Government Action: A Formula for Narrowing Parker v. Brown, 69 Nw. U.L. Rev. 71, 84 (1974).

216. Wiley, supra note 6, at 779 .

217. See sources cited, supra note 9. 
means. It then becomes an unfamiliar task to fit the practice into established antitrust doctrine.

The Supreme Court's recent decision in Fisher v. City of Berkeley ${ }^{218}$ deterinined that the regulation in question was not a violation of the antitrust laws. It did so, however, not because the regulation did not constitute a cartel or an exclusionary practice, but because it did not involve the requisite agreement. In a purely practical sense, it is understandable that the Court would be inchined to adopt this approach, because by doing so it avoided potentially complex issues of liability and exemption. The Court's reasoming, however, is inconsistent with the conception of government imphicit in the Parker doctrine and raises many of the same difficulties as Professor Wiley's capture criterion.

\section{A. Fisher's Categories of Governmental Action: Unilateral, Hybrid, and Corrupt.}

In Fisher, the city of Berkeley enacted an ordimance by popular initiative to "protect tenants from unwarranted rent increases."219 To that end, it established a rent ceilimg based upon rents as of a certain date and created a Rent Stabilization Board to determine annual general adjustments in the rent ceiling and individual adjustınents at the request of landlords. 220 In a very brief opinion, the Court rejected the landlords' antitrust challenge, not because the city's actions were exempt under Parker, but because they did not involve any "contract, coinbination...., or conspiracy" and thus did not conflict with the antitrust laws. ${ }^{221}$

The landlords, for reasons that are unclear, did not contend that the initiative process by whicl the ordinance was adopted constituted an agreement. ${ }^{222}$ Instead, they argued that the regulatory mechanism itself involved an agreement between the landlords and the city and its officials.223 The Court concluded, however, that no such agreeinent was present because the rent ceilings established in the ordinance and adjusted by the board were "unilaterally imposed by government upon

218. 475 U.S. 260,270 (1986).

219. Id. at 262 .

220. Id.

221. Id. at $267-70$ (quoting 15 U.S.C. $\S 1$ (1982)).

222. Id. at 264 (no violation of $\S 4$ or $\S 16$ of the Clayton Act was alleged).

223. Id. at 265-66. Professor Wiley finds it puzzling that the Court analyzes the case as involving an attempt by landlords to have rent control imposed on them. See Wiley, supra note 8, at 157. There should be no mystery, however, when the Court addresses an argument actually raised by the appellants. Moreover, the appellants were not clearly wrong to allege an agreement between themselves and the city. The Court has explicitly endorsed a finding of an agreenent between a "victim" and a "villain" to inprove inaxinuin prices. See Albrecht v. Herald Co., 390 U.S. 145, 150 n.6 (1968). 
landlords to the exclusion of private control."224 The Court found that while the board may choose to respond to a private request for adjustment of the ceiling, "it may decide not to. There is no meeting of the minds here."22s Similarly, the landlords' obedience to the ceilings did not constitute an agreement with government or among themselves to set prices. 226

The Court apparently drew its notion of unilateral action at least in part from the Colgate doctrine, which states that a manufacturer who simply announces the terms on which he will sell to dealers, including the resale price of the product, and refuses to deal with those who do not abide by those terms, is not guilty of resale price maintenance.227 More recently, in Monsanto Co. v. Spray-Rite Service Corp., 228 the Court held that evidence of complaints from dealers about a fellow dealer's pricecutting prior to the termmation of the offending dealer would be insuffcient to establish an agreeinent among dealers and the manufacturer to maintain resale prices. By its obhique reference to Colgate and Monsanto, ${ }^{229}$ the Fisher Court appeared to analogize the relationship between a regulator and the regulated industry to the relationship between a inanufacturer and its dealers.

The Court's reasoning seems to miply that only state laws that purport to authorize purely private agreements will violate section 1 of the Sherman Act. The Court stated, however, that "hybrid" governmental restraints that "merely enforce private marketing decisions" are not umlateral, and therefore may violate section $1 .^{230}$ In Schwegmann Brothers v. Calvert Distillers, Corp., ${ }^{231}$ for example, the state had enforced minimum resale prices imposed by distributors, even against retailers who refused to sign the resale price maintenance agreement. The Fisher Court reasoned that in Schwegmann:

both the selection of ininimum price levels and the exclusive power to enforce those levels were left to the discretion of distributors. While the petitioner-retailer ... may have been legally required to adhere to the levels so selected, the involvement of his supphiers in setting those prices made it impossible to characterize the regulation as umilateral action by the State ....232

224. 475 U.S. at 266.

225. Id. at 267.

226. Id.

227. W. Anderson \& C. Rogers, Antitrust LaW: Policy and Practice $654-57$ (1985).

See United States y. Colgate \& Co., 250 U.S. 300 (1919).

228. 465 U.S. 752,763 (1984).

229. 475 U.S. at $266-67$.

230. Id. at $267-68$.

231. 341 U.S. 384,387 (1951).

232. 475 U.S. at 268 . 
This passage does not identify who the parties to the agreement were. On one reading, it seems to imply that the agreement is between distributors and retailers with governmental compulsion acting merely as a conduit for the agreement. But in its discussion of the Berkeley rent control ordinance, the Court stated that the relationship between government and those who must obey its commands "whether they wish to or not" does not constitute an agreement.233 Acquiescence in a governmental order does not imply agreement with the terms of the order; thus it is immaterial whether the government formulated the terms of the order or merely enforced terms formulated by others. Consequently, in the Court's view, the relevant agreeinent inust have been between the distributors and government. ${ }^{234}$ This conclusion imphes an important conception of the proper functioming of government. As long as government does not independently choose the terms of the order, it agrees with the producers to impose the terms and in doing so violates the Sherman Act. ${ }^{235}$

In a concluding section of Fisher, the Court stated that there may be circumstances in which a conspiracy could be shown, "even where prices are ostensibly under the absolute control of government officials," a circumstance that the Court characterized as "corruption."236 The implication of this passage is that if government officials merely do the bidding of private groups, rather than exercise independent discretion, the action ceases to be unilateral. So interpreted, the passage introduces a version of the capture criterion into the state action doctrine. ${ }^{237}$ Professor Wiley has recognized the similarity between the Court's conception of "corrup-

233. $I d$.

234. See id. at 267-70. Miller v. Hedlund, 813 F.2d 1344 (9th Cir. 1987) offer an interesting comparison. In Miller, the court invalidated Oregon regulations that required beer and wine sellers to file price schedules with the liquor control commission ahead of the prices' effective dates. The regulations also prohibited quantity discounts and required certain price decreases to remain in effect for 180 days. Id. at 1347. Although the price schedules were imposed by each seller on himself or herself rather than on others, the court found that the prices were not due to the unilateral action of the state because "Oregon allow[ed] private parties to set the prices and d[id] not review the reasonableness of those prices." Id. at 1351 . The only parties to such an agreement would be the private parties themselves and the state. 'But see id. at $1350 \mathrm{n} .4$ (affirming judgment in favor of wholesalers because no evidence of concerted actions on their part). See also Kansas ex rel. Stephan v. Lamb, 1987-1 Trade Cas. (CCH) I 67,521 (D. Kan. Feb. 26, 1987) (invalidating minimum price-posting law).

235. See, e.g., 324 Liquor Corp. v. Duffy, 107 S. Ct. 720 (1987) (state's acquiescence in pricesetting scheme insufficient to bring statute within state action exemption).

236. 475 U.S. at 269.

237. For an example of this effect, see City Communications, Inc. v. City of Detroit, 1987-1 Trade Cas. (CCH) $\uparrow 67,618$, at 60,711-12 (E.D. Mich. May 28, 1987) (private individuals who were "effective decisionmaker[s]" in adopting regulation may not be immune from suit, even if municipality is immune). 
tion" and his idea of capture. ${ }^{238}$

Interestingly, the Court explicitly refused to distinguish levels of government in its treatment of the issue of agreement. ${ }^{239}$ Legislators, municipal officers, and adıninistrators act unilaterally when they make the normal choices of government; they only agree with private groups when they are legally compelled to acquiesce in private choices, as in Schwegmann, or when, for their own reasons, they simply enforce a private choice.

Only where legislation is found to conflict "irreconcilably" with the antitrust laws does the level of government responsible for its enactment become important. Legislation that would otherwise be preempted ... may nonetheless survive if it is found to be state action immune from antitrust scrutiny under Parker v. Brown. The ultimate source of that immunity can be only the State, not its subdivisions. ${ }^{240}$

Thus, under Fisher, the issue of whether a regulatory scheine constitutes an agreement depends upon whether the action of the government in imposing the agreement can be characterized as unilateral. This issue, in turn, depends upon whether a government official exercised independent discretion in choosing to impose the particular terms of the restraint. The exercise of that discretion, even in response to pressure from private groups, is an independent act. Where, however, the private group triggers the exercise of governmental power, either by corruption or by invoking a statutory mandate, government enters into an agreement with the private group.

\section{B. A Redefinition of Categories.}

The concept of governmental action imphicit in the Supreme Court's definition of agreement is remarkably similar to the one implicit in Professor Wiley's notion of capture. Both approaches iguore the level of government at which the critical decision is made. In addition, both focus on the extent to which the decision is based upon a conception of the public interest rather than external pressure. Both, in other words, adopt an organic conception of the state, under which "the collectivity becomes as an individual, and the analyst need only search for the underlying value pattern or scale which inotivates independent State action.... The organic State has an existence, a value pattern, and a motivation independent of those of the individual human beings claiming meinbership."241 It is, however, more consistent with constitutional democracy

238. Wiley, supra note 8 , at 169 .

239. 475 U.S. at 265.

240. Id. (citations omitted).

241. J. Buchanan \& G. Tullock, The Calculus of Consent 11 (1965). 
to view the government as "the set of processes, the machine, which allows . . collective action to take place."242 Government exists to provide collective goods to its members, a service that necessarily requires compulsion. ${ }^{243}$ Thus, for the same reasons that the capture preemption standard is incoherent and impractical as a criterion for exemption, the Court's new standard of agreement should be rejected. Just as there is no dichotomy-or at least none that courts can police-between capture and other governmental decisions, there is no dichotoiny between independent and collective government decisions. All governmental decisions in a constitutional democracy are inherently collective, since they are inade in response to political influence and on the delegated authority of the electorate. Equally important, all private action undertaken in response to a legal order involves a decision to agree with the order. The characterizations of consent as the basis for governmental legitimacy, of governinent as based upon a social contract, and of representatives as "agents" of the public ${ }^{244}$ are inore than inetaphors. They represent inevitable economic relationships in repubïcan government.

The discussion in section III deinonstrates that while the legislature may act against the broader interests of its constituents to favor a poitically influential group, a legislative decision to redistribute wealth to such a group through regulation cannot be viewed as a simple response to pohtical pressure. There are agency costs in the legislative agency relationship that inay admit ideological or, nore broadly, representative choices. These points do not, however, suggest that representative choices are unilateral.

One can see the madequacy of the Court's categories by applying thein to earlier cases under the Parker doctrine that found an "agreeinent" in a regulatory program. It is difficult to see, for example, why Parker itself was an exeinption case at all, rather than an instance of lack of agreement: the raisin prorate program was a "true" regulatory scheine "unilaterally" imposed on raisin producers. ${ }^{245}$ Similarly, in Goldfarb v. Virginia State Bar, ${ }^{246}$ the state bar, an agency of the state, had imposed a minimum fee schedule on its ineinbers. ${ }^{247}$ In Fisher's terins, this action apparently would not supply the element of agreement; thus, the findings of agreenent in Parker and Goldfarb can only be reconciled with Fisher on the ground that the regulators in those cases acted

242. Id. at 13.

243. M. OLSON, supra note 34 , at $98-102$.

244. See supra note 68 and accompanying text.

245. The Parker Court assumed, without holding, that the prorate scheme violated the Sherman Act. Parker v. Brown, 317 U.S. 341, 350 (1943).

246. 421 U.S. 773 (1975).

247. Id. at 777-79 \& nn.4-6. 
"corruptly."248 The only basis for such an interpretation is the statement in Goldfarb that the state bar had "foster[ed] anticompetitive practices for the benefit of its members," and "voluntarily joined in what [was] essentially a private anticompetitive activity." 249 Such an interpretation implies that an agency may act "corruptly" by participating in a private price-fixing agreement in ways far inore subtle than the word "corruption" would imply. The distinction seems to be whether the agency is exercising independent judgment or is acting for the benefit of a regulated group with which it has a unity of interests. Only in the former case does the element of a "meeting of the minds" disappear. 250

The reinterpretation of Parker and Goldfarb under the Fisher rationale highlights the error of focusing on the presence or absence of an agreement in antitrust federalisin cases.251 Distinguishing between Fisher's Rent Stabilization Board and Goldfarb's state bar on grounds of their relationships to private interests cannot withstand analysis. All agencies respond to client groups; all agencies must temper their responsiveness by taking into account the interests of others. Because democratic and regulatory choices are necessarily collective, there is an agreement in every instance. Moreover, as shown in section III, courts cannot distimguish matters of degree in this area.

Thus, in considering the issue of proving an agreeinent, the Court's analogy of ordinary vertical cominercial relationships to government's relationship to the electorate ignores the critical fact of representation. Manufacturers act solely in their own interests, forming contractual relations with dealers only to the extent that they foster those interests. Normally, vertical restraints that advance the inanufacturers' interests are efficient; thus the manufacturers' actions in response to the dealers' pleas are not necessarily or even probably intended to advance a deakers' cartel. Such agreements can occur only if the dealers somehow convince the manufacturers, against their own interests, to impose resale price inaintenance for the dealers' cartel. The Colgate doctrime serves, albeit crudely,

248. See supra note 236 and accompanying text.

249. 421 U.S. at 791-92.

250. See supra note 225 and accompanying text.

251. A close reading of Cantor v. Detroit Edison Co., 428 U.S. 579 (1976), suggests an even simpler reason for rejecting Fisher's approach. On the surface, Cantor appears to deal with an instance of state authorization of a private anticompetitive agreement: a tying arrangement between the seller and the purchaser. Such agreements are thought to "foreclose" competitors of the seller from reaching the market and thus to reduce competition in the market for the tied product. But the rent control ordinance in Fisher compels a private agreement in precisely the same way: it permits renters to agree with landlords on a noncompetitive price, thus compelling landlords to refuse to deal with anyone willing to pay the market rate. It is economic nonsense to hold that a government regulation of a term of sale, particularly one aimed at controlling the market price, does not compel private agreements on those terms. 
to limit the extent to which the prohibition on resale price maintenance inhibits efficient distribution relationships. In the case of governmental restraints, there is no such unilateral interest of government. Government officials, whether elected or appointed, are agents of the electorate. As $I$ argue in section $I$, it is certainly the case that differing institutional forms can change the nature of the representative relationship. As a result, officials in differing institutional settings will represent differing elements of the electorate. Nonetheless, officials are always acting most directly in some group's or combination of groups' interest. While officials maximize their own welfare, they do so as a means of fosterimg pohitical support. Their action is thus inevitably collective in a way that a manufacturer's action in response to dealer complaints is not.

The trade association is a closer analogy to government; it acts as a single entity, but in the interests of its members. The action of an association in denying certification of a new product, for exainple, is the collective act of its members, even though the members never exphicitly vote on the issue. ${ }^{252}$ The Goldfarb Court imphicitly recognized this connection when it found an agreement annong the state bar and its members to impose the minimum fee schedules at issue. ${ }^{253}$ While it is true that most state agencies are not as directly cormected to an association of competitors as is a state bar, the fundamental representative relationship reinains in all cases.

It is irrelevant whether the regulatory scheme is designed to advance broader policy goals than simply the economic well-being of a specific interest group. The inquiry thus does not suffer from any of the intractability of the capture preemption test. A municipality may, for exanple, accept the need to displace taxicab competition to avoid congestion and fraud, or it may institute rent control to foster goals of "personhood" and "commumity."254 In either case, the municipality's choice is as collective as it would be if it were made solely to accomplish its redistributive effects. Similarly, the implementation decisions of subordinate administrative bodies involve both this collective choice and new collective choices.

The issue of antitrust federalism, then, is not the presence or absence of an agreenent in state regulation, but whether the inevitable agreenent is in restraint of trade and whether an exemption is appropriate. The first of these issues can be resolved by established economic analysis: does the practice function as a cartel or an exclusionary practice? For all

252. See Radiant Burners, Inc. v. Peoples Gas Light \& Coke Co., 364 U.S. 656, $659-60$ (1961) (per curiam).

253. 421 U.S. at 782.

254. See, e.g., Radin, Residential Rent Control, 15 PHIL. \& PUb. Afr. 350 (1986) (moral, nonutilitarian argument in favor of rent control). 
the reasons market failure and other public interest justifications are inappropriate in the capture preeinption test, it would be inappropriate to introduce thein at this stage of the analysis. ${ }^{255}$ The second issue-and typically the most important one-must be determined by the level of government involved in the decision. The legislature is entitled to exemption for its collective choices, but administrative agencies and nunicipalities are not.

\section{CONCLUSION}

Professor Wiley's conception of capture is so simple and exaggerated that it obscures the critical features of the institutions in which it purportedly occurs. In his critique of the clear-statement approach, his conception of capture leads him to disiniss as insignificant virtually every constitutional protection against factional dominance in legislative processes. This same oversinplification defeats his defense of capture as an analytical standard for preenuption. Most obviously, Professor Wiley fails to consider the characteristics of the legislative process that make such a standard incoherent as a criterion of legitimacy. He likewise ignores the characteristics of the judicial process that render such a standard not only intractable but inconsistent with the courts' role in a representative democracy.

Professor Wiley's concern with whether regulation is the result of capture and the Fisher Colurt's concern with whether the regulation is the "unilateral" act of government are both aimed-quite correctly-at the political failures of regulation. The suggested tests, however, are insupportable in either theory or practice. Nevertheless, only the Court's error requires corrective action. The Court should recognize the essentially collective nature of econonic regulation and return to the clearstatement requirement as the siniplest and most accurate standard of political legitimacy. A realistic focus on the levels of government and their characteristic features is the truest basis for exemption from the antitrust laws.

255. But see Fisher v. City of Berkeley, 37 Cal. 3d 644, 664, 693 P.2d 261, 278, 209 Cal. Rptr. 682,699 (1984) ("[C]ourts must be attentive and sensitive to the legitimate motives behind municipal regulations . . . ."), aff'd on other grounds, 475 U.S. 260 (1986); Note, Municipal Antitrust Liability: Beyond Immunity, 73 CALIF. L. REV. 1829, 1852-53, \& n.145 (1985) (Regulation may be justified as serving to compensate for market failure.). 